CHAPTER 10

\title{
Respiration in the mesopelagic and bathypelagic zones of the oceans
}

\author{
Javier Arístegui ${ }^{1}$, Susana Agustí ${ }^{2}$, Jack J. Middelburg ${ }^{3}$, \\ and Carlos M. Duarte ${ }^{2}$ \\ ${ }^{1}$ Facultad de Ciencias del Mar, Universidad de las Palmas de Gran Canaria, \\ Spain \\ 2 IMEDEA (CSIC-UIB), Spain \\ ${ }^{3}$ Netherlands Institute of Ecology, The Netherlands
}

\begin{abstract}
Outline
In this chapter the mechanisms of transport and remineralization of organic matter in the dark water-column and sediments of the oceans are reviewed. We compare the different approaches to estimate respiration rates, and discuss the discrepancies obtained by the different methodologies. Finally, a respiratory carbon budget is produced for the dark ocean, which includes vertical and lateral fluxes of organic matter. In spite of the uncertainties inherent in the different approaches to estimate carbon fluxes and oxygen consumption in the dark ocean, estimates vary only by a factor of 1.5 . Overall, direct measurements of respiration, as well as indirect approaches, converge to suggest a total dark ocean respiration of $1.5-1.7 \mathrm{Pmol} \mathrm{Ca}^{-1}$. Carbon mass balances in the dark ocean suggest that the dark ocean receives $1.5-1.6 \mathrm{Pmol} \mathrm{Ca}^{-1}$, similar to the estimated respiration, of which $>70 \%$ is in the form of sinking particles. Almost all the organic matter $(\sim 92 \%)$ is remineralized in the water column, the burial in sediments accounts for $<1 \%$. Mesopelagic $(150-1000 \mathrm{~m})$ respiration accounts for $\sim 70 \%$ of dark ocean respiration, with average integrated rates of $3-4 \mathrm{~mol} \mathrm{C} \mathrm{m}^{-2} \mathrm{a}^{-1}$, 6-8 times greater than in the bathypelagic zone $\left(\sim 0.5 \mathrm{~mol} \mathrm{C} \mathrm{m}^{-2} \mathrm{a}^{-1}\right)$. The results presented here renders respiration in the dark ocean a major component of the carbon flux in the biosphere, and should promote research in the dark ocean, with the aim of better constraining the role of the biological pump in the removal and storage of atmospheric carbon dioxide.
\end{abstract}

\subsection{Introduction}

The ocean supports respiratory activity throughout its entire volume. In contrast to the destruction of organic matter, primary synthesis of organic matter is restricted-except for a marginal contribution of chemosynthesis- to the upper 100-200-m skin of the ocean, where sufficient light penetrates to support photosynthesis. The synthesis processes occurring in the photic layer, which encompasses only about $5 \%$ of the water column, have been the object of most of the research effort, and the degradation processes occurring in the dark layers of the ocean remain comparatively poorly studied, despite evidence that the rates involved may be substantial (Williams 2000; del Giorgio and Duarte 2002; Arístegui et al. 2003; Andersson et al. 2004). Yet, the dark ocean is an important site for the mineralization of organic matter, and is the site of long-term organic carbon storage and burial. Hence, the processes occurring in the dark ocean are essential to understand the functioning of and, in particular, carbon cycling in the biosphere. They, therefore, deserve closer attention than hitherto they have been given. 
The reason for the paucity of knowledge on biological processes in the dark layers of the ocean is rooted on an early belief that life in the ocean was confined to its upper, lighted skin. The presence of life in the dark ocean was first demonstrated by collections of deep-sea benthos in the mid-nineteenth century, in the expeditions of Sir John Ross (1817-1818) followed by that of his nephew Sir James Clark Ross aboard the Erebus and Terror (1839-1843). The Challenger expedition (1888) provided evidence of pelagic life in the dark ocean, but the existence of deep planktonic life remained a controversial topic (e.g. Forbe's azoic ocean hypothesis supported by Agassiz, versus contentions of deep planktonic life by Carl Chun) until directly observed in the first immersion by Beede and Barton in 1934, who reached down to $923 \mathrm{~m}$ aboard a bathyscaph. The first evidence of deepwater bacteria was obtained by Portier at the beginning of the twentieth century, during two Prince of Monaco's cruises (1901, 1904), but it was not until the mid-century, when Claude ZoBell and Richard Morita, isolated and counted bacteria from great depths, during the Galathea expedition. Studies on deep-water bacteria regained attention in the 1970s as the result of an accident of the research submersible Alvin (Jannasch and Wirsen 1973), which led to preliminary observations of active microbial metabolism in the dark ocean. These studies were paralleled by studies which implicated the importance of migrating zooplankton (Vinogradov 1970). Pomeroy and Johannes (1968) first measured microplankton respiration in the ocean, by concentrating samples, but the first direct measurements of planktonic respiration at natural densities in the dark ocean were obtained much later, at the turn of the century first by Williams and Purdie (1991) and later by Biddanda and Benner (1997). This body of observations lent support to theoretical speculation on the existence of significant respiration in the dark ocean, necessary to account for deep (300-500 m) oxygen minima in ocean circulation models.

The key role of the dark ocean as the site where the bulk of the excess organic matter produced in the photic layer is mineralized is that it refuels subsequent new production. This represents one of the cornerstones of contemporary views on the biogeochemical functioning of the ocean (Libes 1992). Paradoxically, however, estimates of respiration rate-the process responsible for the mineralization of organic matter-in the dark ocean are still few, representing a small percent of all of the estimates of respiration in the sea. Moreover, these few estimates are scattered both in space and time and are based on in vitro assessments rather than in situ incubations (at depth of sampling). Such estimates are, nevertheless, essential to address critical issues in the cycling of organic carbon in the ocean, which are presently inferred from ocean biology general circulation models rather than from up-scaling from empirical estimates. Yet, even the newest depictions of the global carbon cycle (e.g. Liu et al. 2000) ignore respiratory processes in the dark ocean or derive them, in the absence of any independent estimate, as the residual of budgetary exercises (see discussions in Ducklow 1995; Williams 2000; and del Giorgio and Duarte 2002).

In this chapter, we first provide an account of the sources of organic matter to the dark ocean, which constrain the respiratory activity therein, and then examine the available respiration rates-estimated both directly and indirectly-in each of two operationally defined layers: ${ }^{1}$ (i) the mesopelagic zone, extending from the bottom of the epipelagic layer (about 100-200 m) down to the base of the permanent thermocline, at about $1000 \mathrm{~m}$ depth, and (ii) the bathypelagic zone, defined as the water column and sediments extending from the base of the permanent thermocline to the ocean floor. The separation of the dark ocean in these two layers has been used in the past (e.g. Parsons et al. 1984), and is justified first by the very distinct residence times of these waters (100 and 900 years, respectively; Libes 1992). Second, there is exchange of materials between the mesopelagic layer and the epipelagic layer within biologically relevant timescales, whereas the bathypelagic zone can be considered as a reservoir of

1 Terminology adopted from Parsons et al. (1984). They use $150 \mathrm{~m}$ as the upper limit to the mesopelagic zone; where possible we have adhered to this convention, but this is not always possible when drawing upon other work. We have used the term dark ocean as a collective term to refer to meso- and bathypelagic zones. 
materials at biologically relevant timescales. We provide a discussion of the discrepancies found between the different approaches to estimate respiration in the dark ocean, and conclude by using the estimates of respiration in the dark ocean to derive a global estimate, to be compared with current estimates of export and new production. This exercise provides a revised perspective of the role of the dark ocean in the oceanic carbon cycle.

\subsection{Supply of organic matter to the dark ocean}

The dark ocean receives the excess primary production of the epipelagic zone, as well as additional lateral inputs from the continental margins and other oceanic areas. In addition, migrant zooplankton actively transport organic matter grazed in the epipelagic zone to the dark ocean. There is consensus that the bulk of the organic matter entering the mesopelagic zone is recycled therein, implying that the respiration rates responsible for the recycling must be large. However, there are substantial discrepancies as to the magnitude of organic matter inputs to the dark ocean, so it has been difficult to derive a global estimate of dark ocean respiration from organic matter loading alone.

\subsubsection{Overall rates of export of organic carbon from the photic layer}

The biological carbon pump exports a fraction of the organic carbon produced by oceanic plankton, both in particulate and dissolved form below the thermocline (Antoine et al. 1996). The export of carbon by the biological pump is conventionally regarded to be constrained by the nitrogen input, which is believed to set an upper limit to the organic carbon export equal to the product of the $\mathrm{C} / \mathrm{N}$ ratio in the export organic carbon and the nitrogen supplied to the biogenic layer (Ducklow 1995; Williams 1995; Field et al. 1998). The nitrogen input to the photic zone of the ocean is mainly derived from the internal supply of nitrate through vertical mixing, estimated at $\sim 50 \mathrm{Tmol} \mathrm{Na}^{-1}$ in subtropical waters (Jenkins and Wallace 1992; Lewis 2002), atmospheric inputs (Ducklow 1995; Williams 1995; Field et al. 1998; Luz and Barkan 2000), estimated at about $10 \mathrm{Tmol} \mathrm{Na}^{-1}$ (Longhurst et al. 1995) and nitrogen fixation for which there is little consensus on the global rate (7-14 Tmol N a ${ }^{-1}$; Karl et al. 2002). The assumption that this net production equals the net carbon export by the biological pump is, in turn, based on the assumption that the carbon and nitrogen transport in the upward inorganic and the downward organic fluxes are in similar stoichiometric balance, but the latter assumption is unsupported by current data.

Dissolved organic matter in the photic ocean contains excess carbon relative to nitrogen (mean \pm $\mathrm{SE} C / \mathrm{N}$ ratio $=15.0 \pm 1.1$; Table 10.1) compared to the exported particulate organic matter (global mean $\mathrm{C} / \mathrm{N}$ ratio $=7.8$; Takahashi et al .1985$)$. The twofold

Table 10.1 The distribution of the average atomic C/N ratio in DOM and POM. Values for DOM are near-surface values, averaged when several values were reported

\begin{tabular}{lcl}
\hline Area & C/N ratio & Reference \\
\hline & DOM & \\
NW Mediterranean & 8.7 & Banoub and Williams (1972) \\
NW Mediterranean & 24.6 & Zweifel et al. (1993) \\
NW Mediterranean & 17.0 & Souchou et al. (1997) \\
NW Mediterranean & 15.5 & Doval et al. (1999) \\
NW Mediterranean & 21.3 & C.M.Duarte (unpubl. data) \\
N Atlantic & 20.0 & Williams (1995) \\
NW Atlantic & 13.0 & Gardner and Stephens (1978) \\
NW Atlantic & 14.0 & Hopkinson et al. (1997) \\
Sargasso Sea & 17.1 & McCarthy et al. (1996) \\
Gulf of Mexico & 17.0 & McCarthy et al. (1996) \\
N Pacific & 15.3 & McCarthy et al. (1996) \\
N Pacific & 17.0 & Cherrier et al. (1996) \\
N Pacific & 7.9 & Christian et al. (1997) \\
N Pacific & 20.0 & Karl et al. (1998) \\
NE Pacific & 7.1 & Martin et al. (1987) \\
Equatorial Pacific & 9.0 & Libby and Wheeler (1997) \\
Southern California & 7.1 & Holm-Hansen et al. (1966) \\
Southern California & 14.3 & Williams (1986) \\
Southern California & 18.3 & Hansell et al. (1993) \\
Southern Ocean & 25.0 & Jackson and Williams (1985) \\
Southern Ocean & 8.0 & Kähler et al. (1997) \\
Southern Ocean & 14.8 & S.Agustí (unpubl. data) \\
Arctic Ocean & 14.8 & Wheeler et al. (1997) \\
Mean \pm SE & $15.0 \pm 1.1$ & \\
Global average & POM & \\
\hline & & Takahashi et al. (1985) \\
\hline
\end{tabular}


greater $\mathrm{C} / \mathrm{N}$ ratio in dissolved organic matter compared to particulate organic matter implies that, for the same nitrogen input to the biogenic layer, the potential total organic carbon export is twofold greater if occurring in dissolved organic carbon (DOC) than in particulate (POC) form. The deviations in the dissolved organic $\mathrm{C} / \mathrm{N}$ ratio from the Redfield ratio have been noted in the past (e.g. Williams 1995; Najjar and Keeling 2000; Benner 2002), but have yet to be incorporated into evaluations of the role of oceanic biota on atmospheric carbon uptake. Most previous assessments of the potential importance of the DOC flux to the net carbon export have assumed the DOC/DON ratio to be similar to the Redfield ratio (Antoine et al. 1996). Because the export of organic carbon possible for a given nitrogen supply is twofold greater when the flux occurs as DOC compared to a similar POC flux, even modest changes in the allocation of net community production to POC or DOC may lead to regional differences in the oceanic carbon supply, and possibly respiration, in the dark ocean.

There is an order of magnitude spread in estimates of the organic carbon export from open ocean surface waters, from 0.3 to $2.3 \mathrm{PmolC} \mathrm{a}^{-1}$ (Smith and Hollibaugh 1993; Sambrottto et al. 1993; Ducklow 1995; Hedges and Keil 1995; Emerson et al. 1997; Najjar and Keeling 2000; del Giorgio and Duarte 2002). This variance is attributable, as discussed below, to various degrees of underestimation of the dissolved but, mainly, particulate fluxes.

\subsubsection{Delivery of POC}

The sinking of particles, resulting from dead organisms or plankton excretion, is accepted to be the principal mechanism by which organic carbon is exported from the epipelagic zone to the dark ocean. Much of this organic matter is carried in aggregates, which result from coagulation of smaller particles (Jackson 2002). On average, more than $80 \%$ of the sinking organic matter is remineralized in the upper $1500-2000 \mathrm{~m}$, but there is evidence of regional variations in the remineralization patterns and rates in the mesopelagic zone and thus in the export flux to the dark ocean. Based on the analysis of sediment trap data from 64 open-ocean sites, François et al.
(2002) formulated the hypothesis that export ratio (the fraction of primary production that is exported below the surface) and extent of mineralization through the mesopelagic zone tend to have contrary effects on the overall efficacy of the biological pump. Export ratios are higher in productive high-latitude regions dominated by diatoms, but the efficiency of transfer through the mesopelagic zone in these regions is very low. Mesopelagic remineralization in high-latitude regions is comparatively higher than in low-latitude regions, due to the more labile nature of the organic matter exported, which is mainly in the form of phytoplankton aggregates. In contrast, mesopelagic remineralization rates in low-latitude productive regions are lower because the organic matter exported is relatively refractory (consisting primarily of fast-sinking fecal pellets with carbonate minerals), having already been processed extensively by the food web in the mixed layer (François et al. 2002). In this context, provided the actual primary production is comparable between highand low-latitude regions, the most efficient at transferring carbon to the bathypelagic zone would be the productive low-latitude regions, such as the equatorial upwelling zones, or the Arabian Sea (Antia et al. 2001; François et al. 2002).

The flux of POC into the dark ocean (the export particulate production) can be estimated as the POC collected with floating traps deployed below the surface mixed layer/photic zone. Average annual values obtained from monthly measurements during several years using these traps, both in the subtropical Atlantic (Station BATS; Lohrenz et al. 1992) and central Pacific (Station ALOHA; Karl et al. 1996), yield similar values $\left(0.7-0.9 \mathrm{~mol} \mathrm{C} \mathrm{m}^{-2} \mathrm{a}^{-1}\right)$, about three to fourfold lower than geochemical estimates of new production (Carlson et al. 1994; Emerson et al. 1997); that is, the part of the carbon fixed that is not respired until it has been removed from the epipelagic zone to the dark ocean (Platt et al. 1992). Several studies using particle-reactive natural radio nuclides $\left({ }^{234} \mathrm{Th},{ }^{230} \mathrm{Th}\right.$, and $\left.{ }^{231} \mathrm{~Pa}\right)$ as a tracer for sinking particles, have convincingly demonstrated that both free-floating and moored sediment traps deployed in the mesopelagic zone severely underestimate the particle flux (Buesseler 1991; Buesseler et al. 2000; Scholten et al. 2001; 
Yu et al. 2001). In contrast, traps in the bathypelagic zone seem to intercept the vertical flux of particles more effectively (Yu et al. 2001).

POC fluxes measured from deep-sea (bathypelagic) moored sediment traps have been used to derive empirical models which predict the vertical profile of POC flux in the whole water column, by relating it to primary production and depth (Suess 1980; Betzer et al. 1984; Berger et al. 1987; Pace et al. 1987; Lohrenzen et al. 1992; Antia et al. 2001). In this way, the export particulate production may be estimated from the POC flux at the base of the euphotic zone/mixed layer. The weakness of this approach lies in extrapolating small fluxes measured in the bathypelagic zone to the base of the epipelagic zone, since most of the organic carbon mineralization occurs in the mesopelagic zone. Moreover, these models depend on primary production estimates, which must integrate on the same spatial and temporal scales as sediment traps. Antia et al. (2001) compiled a large set of particle flux ${ }^{230} \mathrm{Th}$ corrected data from deep sediment traps moored in the Atlantic Ocean and estimated, by applying a derived empirical model, that the POC flux at the base of the euphotic zone was about $0.3 \mathrm{PmolCa}^{-1}$. Extrapolating this to the whole ocean would yield a value in the region of $1 \mathrm{PmolCa}^{-1}$, twice the value of previous estimations using uncorrected sediment trap data (e.g. Martin et al. 1987).

\subsubsection{Delivery of DOC}

The export of DOC to the mesopelagic zone may occur by vertical diffusion through the thermocline (e.g. Emerson et al. 1997), or by isopycnal transport and convective mixing of surface rich-DOC waters with deep DOC-impoverished water (e.g. Carlson et al. 1994; Hansell 2002). In addition, there is some evidence that DOC can be adsorbed onto deep-water particles, which provides a mechanism whereby DOC is added to the sinking flux of particulate material (Druffel et al. 1996). Dissolved organic matter can also aggregate by the action of surface charges and microbial activity to form amorphous particles of marine snow, which supplements the sinking flux (e.g. Barber 1966). While the latter are potentially important processes in the transfer
Table 10.2 The average estimated export DOC flux to the mesopelagic zone by vertical diffusive mixing in different areas of the ocean

\begin{tabular}{lcl}
\hline Area & $\begin{array}{c}\text { DOC diffusive flux } \\
\text { (mmol } \mathbf{~ m ~}^{-\mathbf{2}} \mathbf{~ d}^{-\mathbf{1}} \text { ) }\end{array}$ & Reference \\
\hline NW Mediterranean & 1.5 & $\begin{array}{c}\text { Copin-Montégut and } \\
\text { Avril (1993) }\end{array}$ \\
Middle Atlantic Bight & 0.2 & Guo et al. (1995) \\
Central Atlantic & 0.7 & Vidal et al. (1999) \\
Gulf of Mexico & 1.2 & Guo et al. (1995) \\
N Pacific & 2.4 & Emerson et al. (1997) \\
Equatorial Pacific & 8 & Feely et al. (1995) \\
Equatorial Pacific & 1 & Zhang and Quay (1997) \\
Equatorial Pacific & 0.56 & Christian et al. (1997) \\
Equatorial Pacific & 6 & Archer et al. (1997) \\
\hline
\end{tabular}

of DOC to the dark ocean and sediments (Keil et al. 1994), the information available is still insufficient to evaluate their overall impact.

Available average estimates of the oceanic downward DOC flux through vertical diffusive mixing into the water column range from negligible to $8 \mathrm{mmolC} \mathrm{m}^{-2} \mathrm{~d}^{-1}$, with a geometric mean of $1.4 \mathrm{mmolC} \mathrm{m}^{-2} \mathrm{~d}^{-1}$ (Table 10.2). The available estimates have been mostly derived for the subtropical and tropical ocean, but vertical profiles of DOC concentration in high-latitude seas (e.g. Wiebinga and De Baar 1998) also show a gradient from high concentrations in the mixed layer to lower values in the intermediate waters, suggesting that vertical diffusion of DOC may also occur at these latitudes. These estimates rely, however, on the assumption, or calculation, of vertical diffusion coefficients, which may have an uncertainty by an order of magnitude. Hence, although this mechanism of DOC export is unlikely to be as important on a global scale as the POC flux, it still needs to be accurately evaluated (Hansell 2002). Extrapolation to the global ocean, assuming the mean value of DOC export of $1.4 \mathrm{mmol} \mathrm{C} \mathrm{m}^{-2} \mathrm{~d}^{-1}$, yields an estimated global DOC export by diffusive mixing of $0.17 \mathrm{Pmol} \mathrm{Ca}^{-1}$.

In addition to a diffusive, gradient-driven flux of DOC, subduction and convective mixing have been shown to be a significant transport process in areas of deep-water formation, and other areas experiencing seasonally intense convective mixing where DOC seasonally accumulates (Hansell 

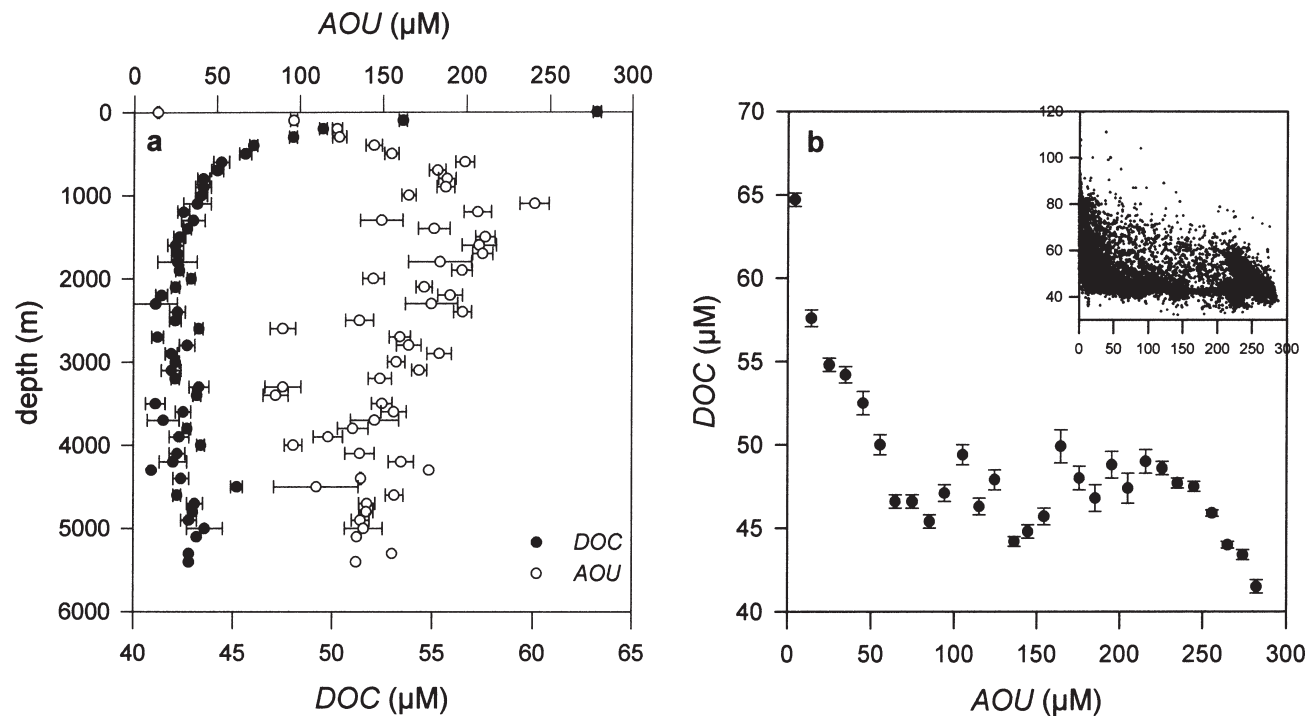

Figure 10.1 DOC and AOU distribution in the dark ocean. (a) The depth distribution of the average (mean \pm SE of data grouped by $100 \mathrm{~m}$ bins, $n=9578$ ) DOC (full circles) concentration and AOU (open circles) in the ocean, and (b) the relationship between DOC and AOU in the ocean. The symbols represent mean \pm SE DOC concentrations of data grouped by $10 \mu \mathrm{MAOU}$ bins $(N=9823)$. The insert in (b) shows the relationship for the raw data $(N=9823)$, which is described in the interval $0<A O U<150$, by the fitted regression equation $\mathrm{DOC}=60.3( \pm 0.2)-0.136( \pm 0.003) \mathrm{AOU}\left(R^{2}=0.28, p<0.0001, n=5541\right)$. The monotonic decrease of DOC when AOU $>225$ corresponds to the oxygen minimum zones of the Arabian Sea, Indian Ocean, and Equatorial Pacific (from Arístegui et al. 2002a).

2002). Hansell and Carlson (2001) have estimated a global DOC export to the aphotic zone (excluding vertical diffusion) of $0.12 \mathrm{PmolCa}^{-1}$, assuming a global new production of $0.6 \mathrm{PmolCa}^{-1}$ and a contribution of DOC to global export of $20 \%$. Since their calculations are based on the magnitude of new production, evidence for a higher value of new production (e.g. 1.3 $\mathrm{PmolC} \mathrm{C}^{-1}$; Sambrotto et al. 1993; Falkowski et al. 1998) would increase the total calculated export by a factor of 2 .

Arístegui et al. (2002a) compiled a large dataset on the relationship between DOC concentration and apparent oxygen utilization (AOU) - the oxygen anomaly with respect to the dissolved oxygen saturation levels-from various oceans. These data revealed a decline in DOC with increasing AOU in the upper $1000 \mathrm{~m}$, albeit with considerable scatter (Fig. 10.1). In contrast, there is no significant decline in DOC with increasing depth beyond $1000 \mathrm{~m}$ (Fig. 10.1), indicating that DOC exported with overturning circulation plays a minor role in supporting respiration in the dark ocean. Assuming a molar respiratory quotient $\left(\Delta \mathrm{CO}_{2} /-\Delta \mathrm{O}_{2}\right)$ of 0.69 (Hedges et al. 2002), the decline in DOC was estimated to account for about $20 \%$ of the AOU within the top $1000 \mathrm{~m}$. This estimate represents, however, an upper limit, since the correlation between DOC and AOU is partly due to mixing of DOC-rich warm surface waters with DOC-poor cold thermocline waters. Removal of this effect by regressing DOC against AOU and water temperature indicated that DOC supports about $10 \%$ of the respiration in the mesopelagic waters (Arístegui et al. 2002a). Nevertheless, since water temperature and DOC covary in the upper water column, the actual contribution of DOC to AOU probably lies between $10 \%$ and $20 \%$.

Considering the above estimates, the overall flux of DOC to the dark ocean can be estimated as the sum of $0.17 \mathrm{Pmol} \mathrm{Ca}^{-1}$ from vertical diffusion and $0.12 \mathrm{PmolCa}^{-1}$ from subduction and convective mixing (cf. $1 \mathrm{PmolCa}^{-1}$ estimate for POC export). Nevertheless, much of the exported DOC by diffusive mixing would be respired in the upper thermocline, contributing little to the ocean-interior 
carbon reservoir, unless it is transported and respired below the depth of the winter mixed layer.

\subsubsection{Transport by migrating zooplankton}

The occurrence of active transport of organic matter by migrating zooplankton was proposed decades ago by Vinogradov (1970). Migrating zooplankton contributes to the transport of particulate and DOC by excretion or fecal pellet dissolution. Migratory processes set in motion $0.08 \mathrm{PmolC}$ (the biomass of the migrant zooplankton) daily between the photic ocean and the dark ocean (Longhurst 1976; Conover 1978). If only a fraction of this organic matter is retained (e.g. excreted) while in the dark zone, this process has the potential to account for a considerable input of organic matter to the dark ocean. Estimates of the actual input involved are, however, still few. Ducklow et al. (2001) and HernándezLeón and Ikeda (Chapter 5) have summarized the available data of downward transport of carbon by diel migrating zooplankton (the active transport) in the Atlantic and Pacific oceans (including the BATS and HOT time-series stations). The daily average value of active organic matter inputs by zooplankton accounts for $0.54 \mathrm{mmol} \mathrm{C} \mathrm{m}^{-2}$ (Hernández-León and Ikeda, Chapter 5). Extrapolating this value to the whole ocean the global transport of organic matter from surface to mesopelagic waters mediated by zooplankton would represent about $0.06 \mathrm{Pm} \mathrm{Ca}^{-1}$. However, since most of the compiled data by the latter authors correspond to oligotrophic regions, the actual contribution of zooplankton to the downward organic carbon flux could be considerably higher when including estimates from high-productive systems.

\subsubsection{Coastal inputs to the dark ocean}

Oceanic waters near continental margins may receive inputs of both particulate and DOC from coastal ecosystems, and because these inputs have not been well constrained, this adds additional uncertainty to the mineralization rates in the dark ocean inferred from mass-balance carbon fluxes. The inputs of total organic carbon (TOC) from the coastal ocean to the dark open ocean have been estimated at $0.17 \mathrm{PmolC}^{-1}$ (e.g. Liu et al. 2000), representing a significant fraction of the global TOC export from the coastal to the open ocean, which have been estimated to range from $0.23 \mathrm{PmolC}^{-1}$ (Gattuso et al. 1998) to $0.5 \mathrm{Pmol} \mathrm{Ca}^{-1}$ (Duarte and Cebrián 1996; Duarte et al. 1999).

These estimates of carbon export from the continental margins are based on carbon mass balances, and there are, as yet, no comprehensive measurements of the actual transport processes supporting this global export. In fact, the exchange rate of water between the global coastal and open oceans remains a matter of speculation, supported by a few case studies (Walsh et al. 1981; Falkowski et al. 1988; Liu et al. 2000). For instance, Wollast and Chou (2001) calculated that $15 \%$ of the primary production in the Gulf of Biscay was exported to the intermediate and deep waters. Mesoscale instabilities, such as filaments, may accelerate the transport of particulate and DOC from the coastal to the open ocean at upwelling regions (e.g. Gabric et al. 1993; Barton et al. 1998). Alvarez-Salgado et al. (2001) estimated that up to $20 \%$ of new production in the NW Spain coastal upwelling region transforms into labile DOC, which is exported offshore to the adjacent open-ocean waters. There is, therefore, a need to directly estimate transport processes to better constrain the input of organic matter from the continental shelves to the dark ocean.

\subsubsection{Summary of organic carbon inputs}

The total export of biogenic carbon from the photic zone (the sum of the open-ocean sinking POC flux, DOC flux and zooplankton active flux, plus TOC advected from coastal ecosystems) should be equivalent, on an annual basis, for the magnitude of the new production. Our review indicates that the sum of the above four carbon inputs amounts to 1.5-1.6 Pmol Ca ${ }^{-1}$, a value close to some recent estimates of new production (Sambrotto et al. 1993; Falkowski et al. 1998), but somewhat below the estimates of export production proposed recently by del Giorgio and Duarte (2002; $2.3 \mathrm{PmolCa}^{-1}$ ). Uncertainties in the estimates of the above fluxes could lead to differences between estimates of new production and export biogenic fluxes. Michaels 
et al. (1994) found a large imbalance in the annual carbon cycle at the Bermuda Atlantic Time-series Station (BATS), which they explained by inaccuracies in the determination of the fluxes of POC using shallow sediment traps. This was corroborated by sediment-trap measurements of the ${ }^{234} \mathrm{Th}$ flux during the same period of study (Buesseler 1991). A more detailed interpretation of the particle fluxes at the BATS station during a decade of sampling revealed that surface sediment trap records could be biased by sampling artifacts due to physical dynamics during deep-mixing events (Steinberg et al. 2001).

\subsection{Pelagic respiration in the dark ocean}

The recent evidence that dark ocean respiration must be important is leading to an increase in the number of direct measurements of rates of metabolism in these layers. These low rates of respiration in deepwater stretch conventional direct methods used to measure planktonic respiration in the euphotic zone to and beyond their limits. Indirect estimations of deep-water respiration have been obtained, based on large-scale geochemical mass balances of oxygen and organic matter fields, although these estimates themselves do not always agree in their magnitude (e.g. Michaels et al. 1994). In this section, we review the different approaches used to estimate respiration in the dark ocean, and compare their results in order to derive an estimate of the global pelagic environment in the dark ocean.

\subsubsection{In vitro oxygen consumption measurements}

Direct measurements of planktonic respiration may be obtained by the in vitro oxygen method (e.g. Williams and Jenkinson 1982). Nevertheless the limited sensitivity of the method has confined generally these measurements to the upper $200 \mathrm{~m}$ of the surface ocean, which are thus overwhelmingly restricted to the very upper layers of the aphotic zone (see Robinson and Williams, Chapter 9). Biddanda and Benner (1997) were, however, able to estimate in vitro microplankton respiration rates in intermediate waters in the Gulf of Mexico, because oxygen consumption was rather high $\left(1-2 \mathrm{mmolO}_{2} \mathrm{~m}^{-3} \mathrm{~d}^{-1}\right)$ in the upper $500 \mathrm{~m}$. They calculated that the integrated respiration within the thermocline $(100-500 \mathrm{~m})$ exceeded the integrated respiration in the top $100 \mathrm{~m}$ (456 and $305 \mathrm{mmolO}_{2} \mathrm{~m}^{-2} \mathrm{~d}^{-1}$, respectively). More recently, respiration rates in the order of $0.2-0.3 \mathrm{mmolO}_{2} \mathrm{~m}^{-3} \mathrm{~d}^{-1}$ have been measured down to $1000 \mathrm{~m}$, in the coastal transition zone region between Northwest Africa and the open ocean waters of the North Atlantic subtropical gyre, by J. Arístegui and C. M. Duarte (unpublished data).

The oxygen method, even when applied in the photic zone, often requires long incubations and there are always concerns that these could induce changes in microbial community structure, biomasses, and rates (see Robinson and Williams, Chapter 9, for a review on bottle effects). Nevertheless, time-series measurements indicate that in most occasions, when samples are handled with care, respiration rates remain uniform (Arístegui et al. 1996, Robinson and Williams, Chapter 9), even during long (ca. $72 \mathrm{~h}$ ) deep-water experiments (J. Arístegui and C. M. Duarte, unpublished), in spite of changes in bacterial production and biomasses (J. M. Gasol, unpublished). The contrasting bottle effects on microbial respiration and biomass or bacterial production (as estimated by leucine and thymidine incorporation) must be further assessed in order to test the applicability of the oxygen method to measure microbial respiration rates during relatively long $(>24 \mathrm{~h}$ ) incubation periods in mesopelagic waters (e.g. Pomeroy et al. 1994).

\subsubsection{Microplankton ETS activity measurements}

At depths where respiration rates are too low to be resolved through the direct measurement of oxygen consumption, the ETS (respiratory Electron Transport System) technique (Packard 1971) has proved to be a useful tool to estimate these rates (Packard et al. 1988). As the enzymatic analysis can be made after the field work, the ETS approach allows the collection of large datasets during field cruises, facilitating the measurement of oceanic respiration 
Table 10.3 Areal estimates of microplankton respiration (R) in the dark ocean. (from Arístegui et al. 2003)

\begin{tabular}{|c|c|c|c|c|}
\hline Ocean & Depth range $(m)$ & $R\left(\mathrm{~mol} \mathrm{Cm}^{-2} \mathrm{a}^{-1}\right)$ & $\begin{array}{c}\text { Number of } \\
\text { stations }\end{array}$ & Method \\
\hline Atlantic (Sargasso Sea) ${ }^{a}$ & $200-1000$ & 1.5 & 8 & ETS \\
\hline Atlantic (Sargasso Sea) ${ }^{a}$ & 1000-bottom & 0.7 & 8 & ETS \\
\hline Atlantic (west Iberia/Morocco) ${ }^{b}$ & $200-1500$ & 6.9 & 1 & ETS \\
\hline Atlantic (meddies) ${ }^{b}$ & $200-1500$ & 6.1 & 2 & ETS \\
\hline Atlantic (Canary Islands) $)^{c}$ & $200-1000$ & 2.4 & 11 & ETS \\
\hline Atlantic (Gulf of Mexico) ${ }^{d}$ & $100-500$ & 118.1 & 7 & Winkler \\
\hline Mediterranean (west) ${ }^{b}$ & $200-1500$ & 6.8 & 2 & ETS \\
\hline Mediterranean (west) ${ }^{\mathrm{e}}$ & $200-3000$ & 1.3 & 8 & ETS \\
\hline Mediterranean (west) ${ }^{f}$ & $200-800$ & 2.2 & 24 & ETS \\
\hline Mediterranean (west) ${ }^{g}$ & $200-1000$ & 1.2 & 10 & ETS \\
\hline Mediterranean (east) ${ }^{h}$ & $200-3000$ & 4.3 & $>10$ & ETS \\
\hline Indian Ocean (Arabian Sea) $)^{i}$ & $200-2400$ & 5.2 & 6 & ETS \\
\hline Indian Ocean (Bay of Bengal) & $200-2400$ & 2.2 & 6 & ETS \\
\hline Pacific Ocean (Guinea Dome) ${ }^{\mathrm{a}}$ & $200-1000$ & 3.9 & $>15$ & ETS \\
\hline Pacific Ocean (Guinea Dome) ${ }^{a}$ & 1000-bottom & 2.6 & $>4$ & ETS \\
\hline Southern Ocean (Indian sector) $)^{j}$ & $200-1000$ & 1.5 & 7 & ETS \\
\hline
\end{tabular}

ETS $=$ Respiratory Electron Transport System activity; Winkler $=$ Winkler oxygen determination.

a Packard et al. 1988; 'b Savenkoff et al. 1993a; CJ. Arístegui, unpublished data; dBiddanda and Benner 1997;

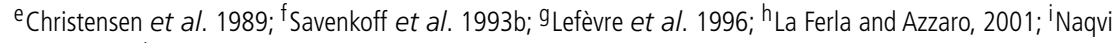
et al. 1996; 'ंArístegui et al. 2002b.

over large temporal and spatial scales. The ETS method estimates the maximum overall activity of the enzymes associated with the respiratory electron transport system under substrate saturation, in both eukaryotic and prokaryotic organisms. ETS activity measurements represent, therefore, potential respiration rates, and hence calculation of in situ respiration rates from ETS activity requires the use of empirically determined algorithms. The R/ETS relationships for deep-water plankton have been derived from monospecific cultures of bacteria and zooplankton (Christensen et al. 1980) grown under laboratory conditions. Thus, respiration rates calculated from ETS activity have to be interpreted with a degree of caution.

The available dark-ocean respiration estimates for microplankton $(<200 \mu \mathrm{m})$ derived from ETS (Table 10.3) have been aggregated into depth-average bins (Arístegui et al. 2003). These estimates yield a relationship between respiration rate and depth (Fig. 10.2(a)) best described by an exponential function of the form,

$$
R\left(\mu \mathrm{molO}_{2} \mathrm{~m}^{-3} \mathrm{~d}^{-1}\right)=18 \mathrm{e}^{-0.00053 z},
$$

which $z$ is the depth in meters. The equation prescribes that respiration rates decline by about $53 \%$ over the mesopelagic layer of the ocean (150-1000 m).

Examination of the residuals (Fig. 10.2(b)) showed an enhanced respiratory activity at 1000-2000-m depth, corresponding to the base of the permanent thermocline, separating the mesopelagic from the bathypelagic layers. Inspection of the individual profiles indicated this enhanced activity to be a consistent feature in various seas and oceans, rather than an anomaly of a particular basin. The origin of these enhancements is unclear, but may derive from mixing of different water masses, or may be produced in situ by migrant zooplankton.

Available data are yet too sparse as to allow the elucidation of differences in the magnitude of microplankton respiration across the different 


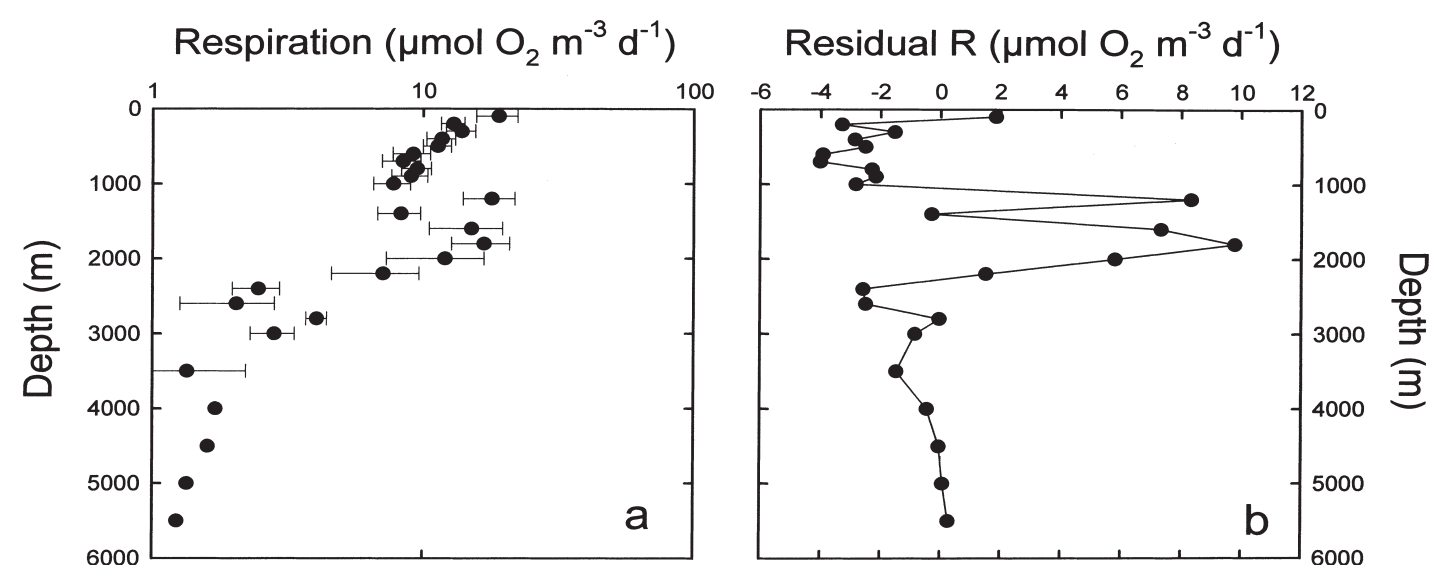

Figure 10.2 The depth distribution of (a) the average ( \pm SE) respiration rate in the dark ocean and (b) the depth distribution of the residuals from the fitted exponential equation. Rates compiled from references in Table 10.4 (from Arístegui et al. 2003).

oceanic provinces of the dark ocean. There are, however, obvious regularities in the various published reports that help constrain the overall microplankton respiration within the dark layers of the global open ocean. In particular, most studies show that integrated respiration, in the layer extending from the bottom of the photic zone to $800-1000 \mathrm{~m}$, is of a similar magnitude as the integrated microplankton respiration in the photic layer of the open ocean (del Giorgio and Duarte 2002), and sometimes greater.

Integration of respiration rates derived from ETS measurements in the dark ocean yield a global respiration ranging from $1.7 \mathrm{Pmol} \mathrm{Ca}^{-1}$, when derived from the areal rates, to $2.8 \mathrm{Pmol} \mathrm{Ca}^{-1}$, when derived from the depth distribution of the rates weighed for the hypsographic curve of the ocean (Arístegui et al. 2003). These rates are comparable to the estimates of the total microplankton respiration in the photic layer, estimated to be $2-4 \mathrm{Pmol} \mathrm{Ca}^{-1}$ (del Giorgio and Duarte 2002; Robinson and Williams, Chapter 9). Examination of the depth-averaged cumulative respiration rate throughout the dark ocean (Fig. 10.3) indicated that $70 \%$ of the microplankton respiration within the dark ocean occurs between 200 and $1000 \mathrm{~m}$ depth. This represents an estimate of $1.2 \mathrm{PmolCa}^{-1}$ for the mesopelagic zone, and $0.5 \mathrm{Pmol} \mathrm{Ca}^{-1}$ for the ocean interior, when derived from the areal rates, although the bathypelagic rates could be overestimated (see Section 10.5).

\subsubsection{Measured rates of bacterial carbon flux}

The rates of bacterial production in the dark ocean constrain their contribution to the respiratory rates there. The vertical profiles of bacterial production show a steep exponential decline spanning two to three orders of magnitude from the surface to the dark ocean (Fig. 10.4; Nagata et al. 2000; Turley and Stutt 2000). Whereas bacterial biomass in the mesopelagic (150-1000 m) and bathypelagic $(1000-4000 \mathrm{~m})$ layers of the water column may exceed that in the photic layer, the integrated bacterial production in each of the two dark layers is much smaller (5-20 fold) than that in the surface ocean (Nagata et al. 2000), indicative that bacterial growth in the dark ocean is generally slow. Cellspecific production rates may be considerably high in particle-associated bacteria from mesopelagic waters (Turley and Stutt 2000). Several authors (Smith et al. 1992; Cho and Azam 1988; Nagata et al. 2000) have proposed that large sinking particles are hydrolyzed to release DOC, which would support production of free-living bacteria both in the mesopelagic and bathypelagic zones.

The total flux of organic carbon through bacteria in the dark ocean (the so-called bacterial carbon flux) can be used to provide a minimum estimate of the long-term, whole-community respiration rate. The bacterial carbon flux $(\mathrm{BC})$ is the sum of bacterial 


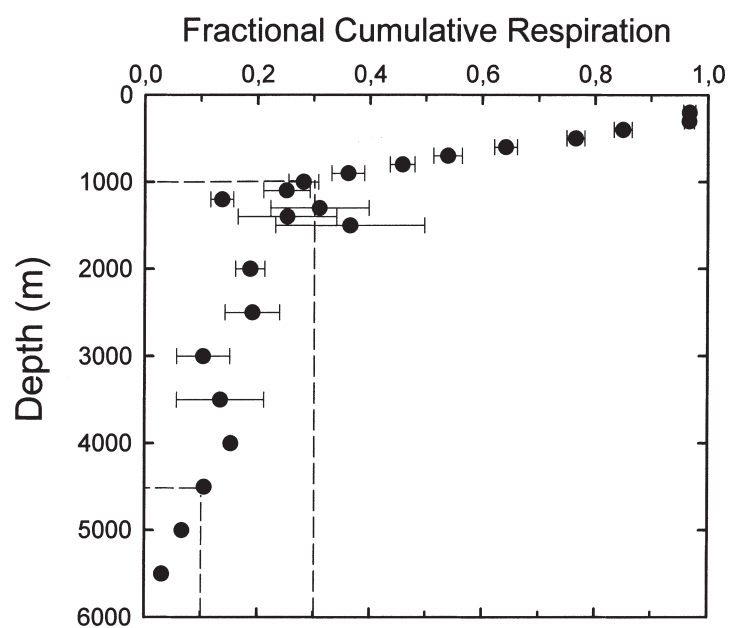

Figure 10.3 The depth distribution of the average ( \pm SE) cumulative respiration rate in the dark ocean. Rates compiled from references in Table 10.4. Dotted lines indicate depths comprising 30\% and $10 \%$ of the water column respiration in the dark ocean (from Arístegui et al. 2003).

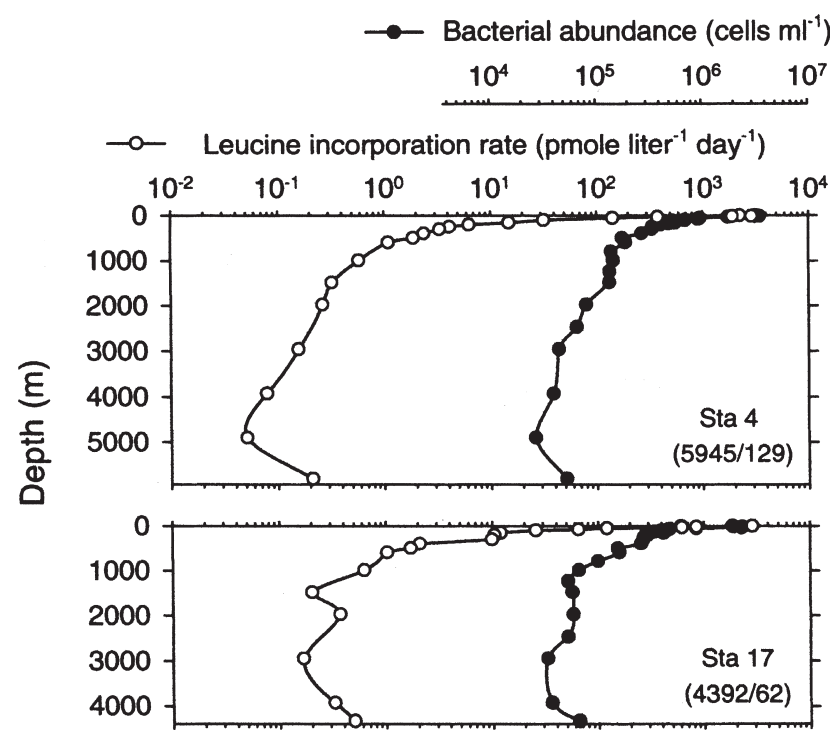

Figure 10.4 Depth profiles of bacterial abundance (closed circles) and leucine incorporation rate (open circles) at two stations from the Subarctic Ocean (from Nagata et al. 2000). production (BP) and bacterial respiration (BR). It may be calculated as the ratio between the bacterial production and the bacterial growth efficiency $(\mathrm{BC}=\mathrm{BP} / \mathrm{BGE}=(\mathrm{BP}+\mathrm{BR}) / \mathrm{BGE})$. The estimation of $B C$ fluxes relies, however, on assumed factors that are highly uncertain: (i) the ratio of leucine incorporation to bacterial production, which may range from $<1$ to $20 \mathrm{Kg} \mathrm{C} \mathrm{mol}^{-1}$ leucine (Kirchman et al. 1985; Simon et al. 1992; Gasol et al. 1998; Sherry et al. 1999), and (ii) the bacterial growth efficiency $(\mathrm{BGE}=\mathrm{BP} /(\mathrm{BP}+\mathrm{BR}))$, which ranges from $2 \%$ to
$70 \%$ in surface waters of aquatic habitats (del Giorgio and Cole 2000), with no published estimates available for the mesopelagic oceanic waters. Hence the estimates of respiration rates derived from bacterial carbon flux in the dark ocean are highly sensitive to poorly constrained conversion factors and, provided these are not rigorously established, must be considered with some degree of caution.

Nagata et al. (2000), using an assumed BGE of 0.2 , calculated that integrated $\mathrm{BC}$ fluxes for different oceanic regions ranged between 1 and 
Table 10.4 Bacterial carbon flux (the total organic carbon consumed by bacteria) in different regions from the dark ocean. Units in $\mathrm{mmol} \mathrm{C} \mathrm{m}{ }^{-2} \mathrm{~d}^{-1}$ (from Nagata et al. 2000)

\begin{tabular}{llll}
\hline Location & $\begin{array}{c}\text { Mesopelagic } \\
\text { zone } \\
(\mathbf{1 0 0 - 1 0 0 0 ~} \mathbf{~})\end{array}$ & $\begin{array}{c}\text { Bathypelagic } \\
\text { zone } \\
(>\mathbf{1 0 0 0} \mathbf{~ m})\end{array}$ & Reference \\
\hline North Pacific Gyre & 6.5 & & Cho and Azam (1988) \\
Santa Monica basin & 42 & & Cho and Azam (1988) \\
Subarctic Pacific & $3.5-13$ & Simon et al. (1992) \\
Indian Ocean & $7.5-51$ & 0.4 & Ducklow (1993) \\
NE Atlantic & 9.8 & $0.5 \pm 0.1$ & Turley and Mackie (1994) \\
Subarctic Pacific & $2.8 \pm 0.9$ & 0.1 & Nagata et al. (2000) \\
N subtropical Pacific & 1.1 & Nagata et al. (2000) \\
\hline
\end{tabular}

$52 \mathrm{mmolC} \mathrm{m} \mathrm{m}^{-2} \mathrm{~d}^{-1}$ for the mesopelagic zone, and between 0.05 and $0.5 \mathrm{mmol} \mathrm{Cm}^{-2} \mathrm{~d}^{-1}$ for the bathypelagic zone (Table 10.4). The geometric mean of the mesopelagic estimates $\left(8 \mathrm{mmol} \mathrm{C} \mathrm{m}^{-2} \mathrm{~d}^{-1}\right)$ represents an annual rate of $2.9 \mathrm{~mol} \mathrm{C} \mathrm{m}^{-2}$, which coincides with the estimate of oxygen consumption in the mesopelagic zone derived from large-scale tracer balances (Section 10.3.5) and from ETS activity (Table 10.3; geometric mean $=2.9 \mathrm{molC} \mathrm{m}^{-2} \mathrm{a}^{-1}$, excluding the very high value reported by Biddanda and Benner 1997).

\subsubsection{Measured mesozooplankton respiration rates}

Because of operational reasons the rates of water column respiration often exclude the respiration of metazoan zooplankton, which can have a significant contribution to planktonic respiration. The estimates of the contribution of mesozooplankton $(>200 \mu \mathrm{m})$ to total respiration in the ocean are highly variable. Joiris et al. (1982) estimated that zooplankton contributed less than $1 \%$ of the total respiration in productive coastal areas, but estimates in the less productive open ocean seem to be higher. Early studies in open ocean sites suggested a contribution of less than 5\% (Pomeroy and Johannes 1968), and subsequent studies report similar ranges (Williams 1981; Holligan et al. 1984; Hernández-León et al. 2001). On the basis of the reported rates, the contribution of zooplankton to total plankton respiration was estimated by del Giorgio and
Duarte (2002) at about $0.22 \mathrm{PmolCa}^{-1}$ (or about an additional $10 \%$ of the pelagic respiration in the dark ocean). This value agrees with the global estimate $\left(0.21 \mathrm{PmolCa}^{-1}\right)$ calculated by Hernández-León and Ikeda (Chapter 5) from a major review of zooplankton respiration in the mesopelagic (0.18 $\mathrm{PmolCa}^{-1}$ ) and bathypelagic $\left(0.03\right.$ Pmol Ca $\left.^{-1}\right)$ zones, based both on biomass and ETS activity.

\subsubsection{Inference of organic matter mineralization from oxygen fields}

Early insight into the likely importance of respiratory processes in the dark ocean was derived from the examination of the distribution of oxygen and organic matter fields. Evidence of a deep oxygen minimum at depths ranging from $100 \mathrm{~m}$ in the Indian Ocean to $1000 \mathrm{~m}$ depth in the Pacific Ocean suggested significant oxygen consumption at those depths, although the presence and position of the oxygen minimum may be largely a result of oceanic circulation (cf. Wyrtki 1962). Examination of the AOU in the dark ocean, also provided evidence suggesting an important respiratory activity there (e.g. Broecker and Peng 1982). In fact, the distribution of AOU in the dark ocean parallels the path of dark ocean circulation, indicating that as much as $195 \mathrm{mmol} \mathrm{O}_{2} \mathrm{~m}^{-3}$ is removed from the oldest dark oceanic waters (Fig. 10.5).

The link between the distribution of AOU and the age of the water masses is so strong that a 

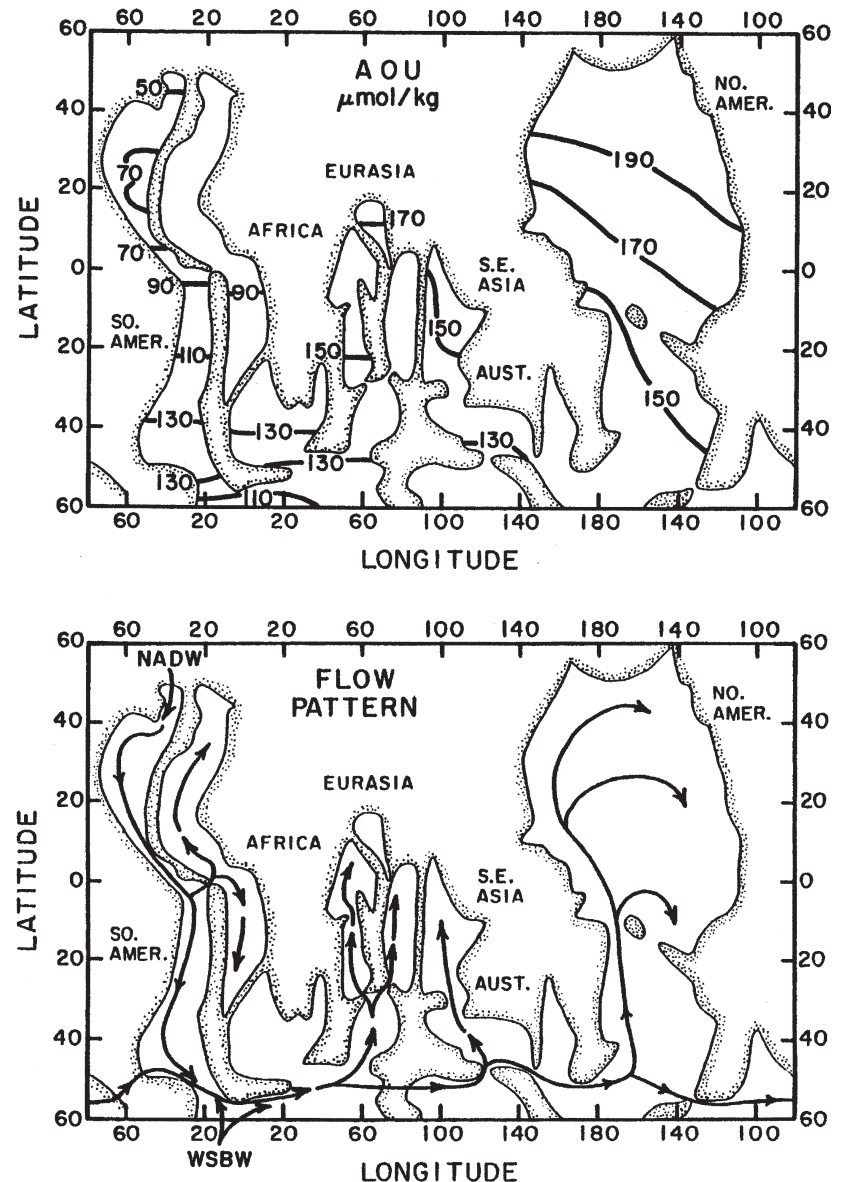

Figure $10.5 \mathrm{AOU}$ in the dark ocean. (a) The distribution of AOU $\left(\mu \mathrm{mol} \mathrm{kg}{ }^{-1}\right)$ at 4000 -m depth in the world's major ocean basins, and (b) deep-water mass flow pattern at the same depth (from Broecker and Peng 1982). relationship between $\mathrm{AOU}$ and an independent estimate of the age of the water masses can be used to derive long-term average estimates of respiration (the oxygen utilization rate, OUR) in the dark ocean (cf. Jenkins and Wallace 1992). The first calculations of OURs were based on 3D advection-diffusion models based on geostrophic velocity estimates (Riley 1951). More recent approaches include boxmodel estimates, and advective-diffusive estimates, using tracer mass-balance calculations. Several tracers (e.g. ${ }^{228} \mathrm{Ra},{ }^{3} \mathrm{H},{ }^{3} \mathrm{He}, \mathrm{CFC}$ ) have been satisfactorily applied to estimate OURs, by providing an apparent age for a water parcel with respect to its last exposure to the sea surface (see review by Jenkins and Wallace 1992, and references therein). Despite the rather different approaches, all these techniques yield similar absolute OUR estimates ( $\left.\sim 5-6 \mathrm{molO}_{2} \mathrm{~m}^{-2} \mathrm{a}^{-1}\right)$ for the subtropical North Atlantic Ocean, adding confidence to the results. Unfortunately, these techniques can only be applied where the age of the water mass can be calculated with relative precision and mixing effects can be assumed to be relatively unimportant, which is an uncommon situation. Consequently, these techniques have not yet allowed global estimates of respiration in the dark ocean.

Oxygen consumption rates in the mesopelagic zone have been also deduced from dissolved oxygen profiles and particulate barium stocks. Dehairs et al. (1997) used a 1D advection/diffusion inverse model of the steady-state distribution of conservative and non-conservative tracers in 
the water column, with the aim of estimating oxygen consumption in the Southern Ocean. The weakness of this method lies, as well as in other advection/diffusion models, on the difficulty associated with the determination of eddy diffusivity. Their estimated oxygen consumption rates, integrated between 175 and $1000 \mathrm{~m}$, ranged from 1 to $6 \mathrm{mmolO}_{2} \mathrm{~m}^{-2} \mathrm{~d}^{-1}$. These rates, extrapolated to a yearly basis $\left(0.4-2.2 \mathrm{~mol} \mathrm{O}_{2} \mathrm{~m}^{-2} \mathrm{a}^{-1}\right)$ are somewhat lower than those estimated for the mesopelagic zone in the subtropical North Atlantic (Jenkins and Wallace 1992), but broadly agree with ETS estimates in the mesopelagic zone of the Southern Ocean (Arístegui et al. 2002b).

\subsubsection{Inferences of organic matter mineralization from carbon fluxes}

Particulate organic carbon is solubilized to yield DOC, which is then partially respired by bacteria, as it sinks through the water column. This results in an exponential decrease in the flux of POC with depth, when sinking across the water column below the euphotic zone. Suess (1980) was the first to propose a model, based on sediment trap data, to predict the flux of particulate organic carbon at a given depth. His model, as well as other subsequent ones (e.g. Betzer et al. 1984; Berger et al. 1987; Pace et al. 1987), predicts the particle flux $J_{z}$ at a given depth $(\mathrm{z}$ in meters), as a function of depth and the surface primary production $(P)$ through the expression (Suess 1980):

$$
J_{z}=P / 0.024 z
$$

Assuming a global primary production rate of $3 \mathrm{PmolCa}^{-1}$ (Antoine et al. 1996), the fraction of POC respired between 150 and $1000 \mathrm{~m}$ is estimated to be $0.7 \mathrm{PmolCa}^{-1}$. If photosynthesis were closer to $4 \mathrm{PmolCa}^{-1}$ (del Giorgio and Duarte, 2002), the fraction respired in the 150-1000 m would be $\sim 1 \mathrm{PmolCa}^{-1}$. According to the Suess expression:

$$
\text { Fraction POC respired }=1-\frac{1}{(0.024 z+0.21)}
$$

95\% of the POC entering the dark ocean is respired within the mesopelagic zone (i.e. above 1000-m depth), a percentage higher than estimated through other approaches. The Suess relationship is based, however, on sediment trap data, which seem to underestimate particulate fluxes (see above), due to hydrodynamics, resuspension, swimmers, and degradation of organic matter between settling and trap collection, as well as to the inefficacy in the trapping performance (Antia et al. 2002).

\subsubsection{Inference of organic matter mineralization from sediment oxygen consumption}

Particulate organic matter fluxes based on sediment traps are often too low to sustain sedimentary demands (Smith et al. 1992). Sediments, however, provide the ultimate sediment trap and integrate carbon fluxes over a considerable period of time. Following these considerations, Andersson and coworkers have used sediment oxygen consumption rates to derive an expression for the depth attenuation of the organic carbon flux in the ocean (Andersson et al. 2004, see also, Wijsman 2001):

$$
\text { Flux }=31.5 \mathrm{e}^{-0.018 z}+6.5 \mathrm{e}^{-0.00046 z}
$$

where the flux of carbon is given in $\mathrm{mmolO}_{2} \mathrm{~m}^{-2} \mathrm{~d}^{-1}$ and $z$ is water depth in meters. At steady state, the divergence of this organic carbon flux with depth should balance oxygen utilization rate at that depth (Suess 1980). Consequently, differentiation of the above equation with depth gives an expression for the oxygen utilization rate as a function of water depth $\left(\mathrm{mmolO}_{2} \mathrm{~m}^{-3} \mathrm{~d}^{-1}\right)$ :

$$
\text { OUR }=0.56 \mathrm{e}^{-0.018 z}+0.0028 \mathrm{e}^{-0.00046 z}
$$

The flux equation was combined with ocean bathymetry to derive integrated sediment respiration. Integrated water column respiration was estimated from the difference in organic carbon flux between the top and bottom of the sections considered. Table 10.5 shows the derived respiration rates for the dark water column and sediments. These rates correspond only to particulate organic carbon remineralization, and do not account for the 
Table 10.5 Global estimates of respiration in the dark water column and sediments ( $\left.\mathrm{Pmol} \mathrm{Ca}^{-1}\right)$, derived from oxygen consumption measurements in sediments (from Andersson et al. 2004)

\begin{tabular}{lcc}
\hline & $\begin{array}{c}\text { Mesopelagic zone } \\
(\mathbf{1 0 0}-\mathbf{1 0 0 0 ~} \mathbf{~})\end{array}$ & $\begin{array}{l}\text { Bathypelagic zone } \\
(>\mathbf{1 0 0 0} \mathbf{~ m})\end{array}$ \\
\hline Water & 0.63 & 0.23 \\
Sediments & 0.04 & 0.09 \\
\hline
\end{tabular}

Oxygen units converted to carbon units using a respiratory quotient, $\mathrm{RQ}=0.69$.

dissolved fraction, in contrast to other approaches (AOU/tracers, ETS measurements).

\subsubsection{Inference of organic matter mineralization from ocean biology general circulation models}

Estimates derived from modeling exercises are rendered uncertain by the influence of mixing processes, because results are highly sensitive to the parameterization of diffusivity, ventilation, and mixing rates, and are stacked to a fixed depth which does not extend to the entire water column (e.g. Bacastow and Meier-Reimer 1991; Najjar and Keeling 2000). Approaches based on general circulation models also require assumptions on the carbon to nutrient stoichiometry, which can be highly variable depending on whether remineralization is based on POC or DOC data (Bacastow and Meier-Reimer 1991). Moreover, the model results are highly dependent on the model formulation (e.g. Ducklow 1995), so that the model output requires independent verification. Because of these limitations, there are, at present no consistent estimates of total respiration in the dark ocean derived from general circulation models.

\subsection{Benthic respiration in the dark ocean}

Sediments are the ultimate depository of particles in the ocean. Particulate organic matter arriving at the seafloor has been subject to degradation in the photic and aphotic zones of the water column. Consequently, only a very small proportion of the surface water primary production (on the order of a few percent) reaches the seafloor. Moreover, virtual all organic matter delivered to the sediments is respired in the top few decimeters so that little organic matter is buried. Nevertheless it is sufficient to support a large number $\left(3.5 \times 10^{30}\right)$ and high biomass (25 PmolC) of prokaryotic cells in subsurface oceanic sediments (Whitman et al. 1998) that appear to be metabolically active ( $\mathrm{D}^{\prime} \mathrm{Hondt}$ et al. 2002).

The global organic carbon burial, recently estimated at $13 \mathrm{TmolCa}^{-1}$ (range $11-18 \mathrm{TmolCa}^{-1}$; Hedges and Keil 1995) represents only a fraction (4-9\%) of global sedimentary mineralization (190 Tmol Ca ${ }^{-1}$, Jørgensen 1983; $220 \mathrm{TmolCa}^{-1}$, Smith and Hollibaugh, 1993; 140-260 $\mathrm{TmolCa}^{-1}$, Middelburg et al. 1997; $210 \mathrm{Tmol} \mathrm{Ca}^{-1}$, Andersson et al. 2004). This is often expressed in terms of the burial efficiency: that is, the organic carbon accumulation rate below the diagenetic active surface layer divided by the organic carbon delivery to sediment surface. Burial efficiencies are typically less than $1 \%$ and $10 \%$ for deep-sea and ocean slope sediments, respectively, but may be much higher for rapidly accumulating shallow-water sediments (Hedges and Keil 1995). Consequently, most organic carbon burial occurs in shallow sediments (>80-90\%; Hedges and Keil 1995; Middelburg et al. 1997).

Respiration of organic matter in marine sediments has received a fair measure of attention and major advances in our understanding and capabilities to measure and model it have been made. While respiration rates for abyssal waters are usually based on indirect methods and depend on empirical relations and model parameterizations, this is not the case for sediment respiration. Sediment respiration is usually based on sediment oxygen consumption, because these can be measured directly and in situ by incubation with autonomous benthic landers (Tengberg et al. 1995). Moreover, a simple reaction-diffusion model combined with in situ microelectrode data can be used to derive oxygen fluxes in deep-sea sediments (Reimers et al. 2001). Oxygen fluxes provide an accurate measure for total sediment respiration because aerobic respiration accounts for almost all organic 
matter mineralization in deep-sea sediments and most mineralization in slope sediments (Epping et al. 2002) and because most products of anaerobic mineralization (ammonium, reduced iron and manganese, sulfide) are efficiently re-oxidized (Soetaert et al. 1996, and see Middelburg et al. Chapter 11). Oxygen consumption coupled to re-oxidation of reduced components varies from about $20 \%$ in deepsea sediments (oxygen consumption due to nitrification) to more than $60 \%$ in shelf sediments (Soetaert et al. 1996). Although oxygen consumption does not provide a good measure for aerobic respiration in slope sediments, it gives a reliable measure of total respiration because of efficient, quantitative re-oxidation of anaerobic respiration products (Jørgensen 1982).

Sediment oxygen consumption rates range over 4 orders of magnitude from more than 200 in coastal sediments to about $0.02 \mathrm{mmol} \mathrm{O}_{2} \mathrm{~m}^{-2} \mathrm{~d}^{-1}$ in some deep-sea sediments (Jørgensen 1983; Middelburg et al. 1997; Andersson et al. 2004). A number of researchers have derived empirical relationships from compiled datasets of sediment oxygen consumption. The depth attenuation of sediment oxygen consumption rates has been traditionally described with a power function with exponents varying from -0.36 to $-0.93 \mathrm{~km}^{-1}$ (Devol and Hartnett 2001), although other parameterizations have also been proposed: exponential and double exponential relations. These datasets have also been used to derive global estimates of benthic respiration below $1000 \mathrm{~m}$, which range about tenfold from 0.01 (Jørgensen 1983), 0.05 (Jahnke 1996), 0.08 (Christensen, 2000) to $0.13 \mathrm{PmolO}_{2} \mathrm{a}^{-1}$ (Andersson et al. 2004). Differences between these estimates result from differences in data availability, data selection criteria (in situ only or all available data), and the depth range considered to derive the predictive equations used for upscaling (below $1000 \mathrm{~m}$ only or all depths). The latter, most recent estimate, is based on a larger dataset and comprises only in situ total sediment community consumption estimates and has therefore been selected. Jørgensen (1983) and Andersson et al. (2004) also obtained estimates for total sediment respiration of 0.19 and $0.31 \mathrm{PmolO}_{2} \mathrm{a}^{-1}$, respectively, with sediments at intermediate depths $(100-1000 \mathrm{~m})$ consuming
$0.05 \mathrm{PmolO}_{2} \mathrm{a}^{-1}$. Sedimentary respiration below the photic zone then amounts to $0.18 \mathrm{PmolO}_{2} \mathrm{a}^{-1}$ (58\% of total sediment respiration).

\subsection{Synthesis: budgeting respiration in dark ocean}

The pelagic rates of oxygen consumption in the bathypelagic zone ( $>1000 \mathrm{~m}$ ) are extremely low and very difficult to measure, resulting in rather few direct measurements of respiration in the ocean's interior. In spite of the scarcity of data, the preceding discussion clearly indicates that the variance in the estimates of respiration rates in the bathypelagic ocean and sediments, where mixing is a minor source of error, is considerablly lower than that in the mesopelagic zone. Fiadeiro and Craig (1978) calculated a rate of respiration for the whole water column below $1000 \mathrm{~m}$ of $2 \mu \mathrm{O}_{2} \mathrm{l}^{-1} \mathrm{a}^{-1}$ $\left(0.24 \mu \mathrm{mol} \mathrm{O}_{2} \mathrm{~m}^{-3} \mathrm{~d}^{-1}\right)$, similar to other estimates available for the ocean interior based on oxygen fields and large-scale models (Riley 1951; Munk 1966; Broecker et al. 1991). These rates are comparable in magnitude to the deep-water estimates derived from oxygen consumption in sediments (Table 10.5), but considerablly lower than estimates derived from ETS measurements (Table 10.3). The bathypelagic ETS rates were derived from only 25 measurements, and presumably overestimated the global rate (Arístegui et al. 2003). Excluding the global rate derived from ETS, the resulting estimates converge to a total respiration rate in the bathypelagic water column of about $0.1-0.2 \mathrm{PmolCa}^{-1}$ (cf. $0.1 \mathrm{Pmol} \mathrm{Ca}^{-1}$ for the sediments).

The global respiration rate in mesopelagic waters (which is thought to represent the bulk of the total dark ocean respiration) is not as well constrained as that of the bathypelagic zone, and there is no accepted global estimate. Nevertheless, in spite of the uncertainties inherent to the different methods used to calculate respiration in the mesopelagic zone, our synthesis shows that the average integrated rates obtained from direct metabolic measurements (oxygen consumption, ETS activity, bacterial carbon flux) vary between 3 and $4 \mathrm{molC}^{-2} \mathrm{a}^{-1}$, and converge to global range of $1-1.3 \mathrm{PmolC}^{-1}$, when extrapolated to 
the whole ocean. These estimates of global dark ocean respiration can be placed within the context of other estimates of respiration based on indirect approaches, which include carbon mass balances, and indirect estimates based on benthic respiration and POC flux. The estimates derived from the different approaches that we have reviewed are synthesized in Table 10.6.

There is a growing number of published oceanic carbon mass balances (i.e. carbon input into the dark ocean minus carbon output) that implicitly contain estimates of the total respiration in the dark ocean. The respiration rate in the dark ocean can be estimated as the difference between the organic carbon inputs to the dark ocean and the organic carbon burial in deep-sea sediments. This massbalance analysis yields highly divergent respiration rates, ranging from 0.3 to $2.3 \mathrm{Pmol} \mathrm{Ca}^{-1}$ (Sambrottto et al. 1993; Smith and Hollibaugh 1993; Ducklow 1995; Hedges and Keil 1995; Emerson et al. 1997; Najjar and Keeling 2000; del Giorgio and Duarte 2002). Whereas the negative term of the massbalance equation, the organic carbon burial, is relatively well-constrained, that of the additive term, the organic carbon inputs, is not. Indeed, estimates of organic carbon inputs to the dark ocean have been increasing from low estimates of about $0.4 \mathrm{Pmol} \mathrm{Ca}^{-1}$, considering only POC inputs from the photic layer (e.g. Martin et al. 1987), to estimates of $>2 \mathrm{Pmol} \mathrm{Ca}^{-1}$ when considering the TOC flux, the active flux mediated by zooplankton and inputs from the continental shelf (del Giorgio and Duarte 2002). In contrast, estimates of organic carbon burial in the deep sea have remained relatively stable at about $0.005 \mathrm{PmolC}^{-1}$. Table 10.6 summarizes the estimates of organic carbon inputs to the dark ocean

Table 10.6 Summary of annual organic carbon fluxes in the dark water-column

\begin{tabular}{|c|c|c|c|}
\hline & $\begin{array}{l}\text { Chapter } \\
\text { Section }\end{array}$ & $\begin{array}{c}\text { Areal } \\
\left(\mathrm{molCm}^{-2} \mathrm{a}^{-1}\right)\end{array}$ & $\begin{array}{c}\text { Global } \\
\left(\text { Pmol Ca }^{-1}\right)\end{array}$ \\
\hline \multicolumn{4}{|l|}{ Organic carbon inputs to the mesopelagic zone } \\
\hline POC sedimentation (corrected for ${ }^{230} \mathrm{Th}$ ) & 10.2 .2 & 3.1 & 1 \\
\hline DOC export by diffusive mixing (geomean Table10.2) & 10.2 .3 & 0.5 & 0.17 \\
\hline DOC export by convection and subduction & 10.2 .3 & 0.4 & 0.12 \\
\hline POC export by migrating zooplankton & 10.2 .4 & 0.2 & 0.06 \\
\hline TOC advection from the coast & 10.2 .5 & 0.5 & 0.17 \\
\hline \multicolumn{4}{|l|}{ Mesopelagic water column respiration } \\
\hline Bacterial carbon flux (geomean Table 10.4) & 10.3 .3 & 2.9 & 1 \\
\hline Microplankton respiration (from ETS) & 10.3 .2 & $3.7-6.2$ & $1.2-2$ \\
\hline Mesozooplankton respiration (from ETS) & 10.3 .4 & 0.56 & 0.18 \\
\hline Inference from AOU/tracers (North Atlantic) & 10.3 .5 & $3.5-4$ & $1.1-1.3$ \\
\hline Inference from oxygen fields/barium (Southern Ocean) & 10.3 .5 & $0.3-1.5$ & $0.1-0.5$ \\
\hline Inference from carbon fluxes & 10.3 .6 & $2.2-2.9$ & $0.7-1$ \\
\hline Inference from sediment oxygen consumption (Table 10.5) & 10.3 .7 & 1.9 & 0.63 \\
\hline Inference from carbon-mass-balance ${ }^{a}$ & & $5.6-7.1$ & $1.8-2.3$ \\
\hline \multicolumn{4}{|l|}{ Bathypelagic water column respiration } \\
\hline Bacterial carbon flux (geomean Table 10.4) & 10.3 .3 & 0.27 & 0.08 \\
\hline Microplankton respiration (from ETS) & 10.3 .2 & $1.5-2.5$ & $0.5-0.8$ \\
\hline Mesozooplankton respiration (from ETS) & 10.3 .4 & 0.09 & 0.03 \\
\hline Inference from sediment oxygen consumption (Table 10.5) & 10.3 .7 & 0.62 & 0.2 \\
\hline Inference from carbon-mass-balance ${ }^{a}$ & & $0.34-0.4$ & $0.11-0.13$ \\
\hline Inference from oxygen fields/circulation models & 10.5 .2 & $0.15-0.43$ & $0.05-0.14$ \\
\hline
\end{tabular}

adel Giorgio and Duarte (2002); mesopelagic area $=3.29 \times 10^{14} \mathrm{~m}^{2}$; bathypelagic volume $=8.4 \times 10^{17} \mathrm{~m}^{3}$. 
discussed in Section 9.2. The sum of our reviewed estimates yields a global input of organic carbon to the dark ocean of about 1.5-1.6 PmolC $\mathrm{P}^{-1}$. This estimate results from the sum of POC sedimentation (1 PmolC $\mathrm{C}^{-1}$ ), DOC delivered by vertical diffusion, isopycnal transport, and convective mixing $\left(0.29 \mathrm{Pmol} \mathrm{C} \mathrm{a}^{-1}\right)$, active transport of POC and DOC by migratory zooplankton $\left(0.06 \mathrm{PmolC}^{-1}\right)$, and advection of POC and DOC from coastal waters (0.17 Pmol Ca $\left.{ }^{-1}\right)$.

An alternative approach used to derive global respiration rates in the dark ocean is based on the rates of oxygen consumption in sediments (Wijsman 2001; Andersson et al. 2004). The method yields an estimate for the mesopelagic respiration around 0.6 PmolC $\mathrm{Pa}^{-1}$ (Table 10.6), much lower than the $1.2 \mathrm{PmolC}^{-1}$ that results from the extrapolation of areal rates obtained by direct measurements of microplankton ETS respiratory activity in the mesopelagic zone (Arístegui et al. 2003). Andersson's approach is based only on particulate organic matter, while the ETS method measures total microplankton respiration, which includes both dissolved and particulate organic carbon. This difference could account for some, but probably not all, of the difference between the estimates derived from the two methods since, as was discussed in previous sections, DOC seems to account for only $10-20 \%$ of the oxygen consumption in the dark ocean (Arístegui et al. 2002a). In this regard, the estimates of respiration rates derived from ETS generally agree with oxygen consumption estimates derived from bacterial carbon flux or inferred from AOU/tracers (Table 10.6). Figure $10.6 \mathrm{com}$ pares the global respiration rates derived from ETS measurements and oxygen consumption in sediments, with oxygen utilization rates in the subtropical North Atlantic estimated from large-scale tracer balances. If we consider that the latter estimates are typical of the whole ocean, the rates derived from oxygen consumption in sediments would underestimate the mesopelagic respiration by $30 \%$, while the ETS estimates would match the AOU/tracers measurements. Conversely, and as argued above, the ETS-derived rates may severely overestimate respiration in the bathypelagic zone, where the method based on oxygen consumption in sediments

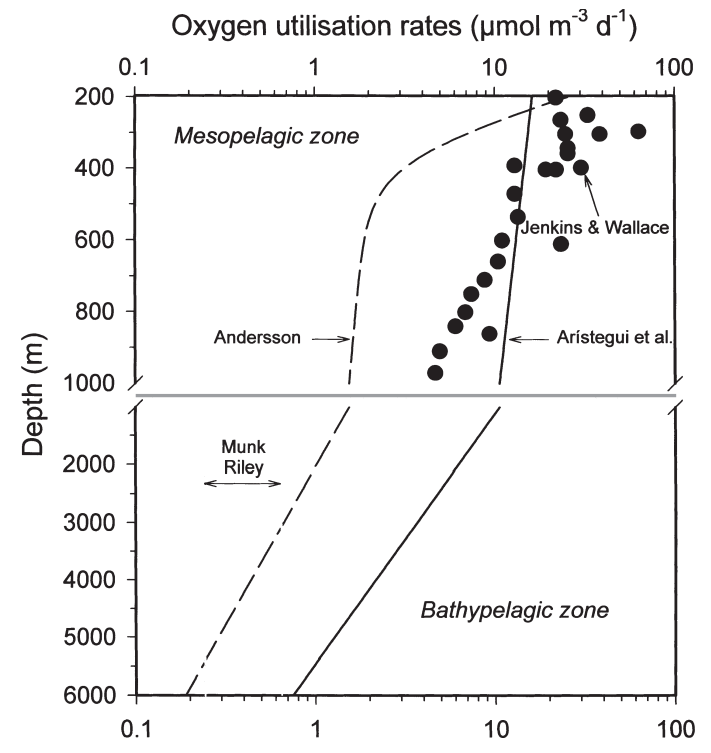

Figure 10.6 Global estimates of OUR versus depth, derived from ETS measurements (Arístegui et al. 2003) and oxygen consumption in sediments (Andersson et al. 2004). Rates are compared with OUR in the North Atlantic mesopelagic zone $(<1000 \mathrm{~m})$, estimated from AOU and large-scale tracers (Jenkins and Wallace 1992), and with oxygen consumption in the bathypelagic zone (>1000 m) derived from oxygen fields in the North Atlantic (Riley 1951) and Pacific Ocean (Munk 1966) (see text for details).

yields more accurate respiratory rates. Hence, it seems preferable to combine both approaches (the AOU/tracers measurements and ETS for the mesopelagic, and the oxygen consumption in sediments for the bathypelagic) to obtain an estimate of respiration in the dark ocean, and this yields a global rate of about 1.2-1.4 $\mathrm{PmolCa}^{-1}$. Respiration of zooplankton $\left(0.2 \mathrm{Pmol} \mathrm{Ca}^{-1}\right)$ and sediments $\left(0.13 \mathrm{Pmol} \mathrm{Ca}^{-1}\right)$ added to this estimate, yields a global dark respiration of 1.5-1.7, which is consistent with the calculated global inputs of organic matter to the dark ocean reported above (Table 10.6), but somewhat lower than the total dark ocean respiration estimate of $1.9-2.4 \mathrm{Pmol} \mathrm{C} \mathrm{a}^{-1}$ proposed by del Giorgio and Duarte (2002). Figure 10.7 represents a tentative organic carbon budget for the dark ocean, where organic carbon inputsaccording to the reviewed data of Table 10.6have been slightly rounded to look for a balance. 


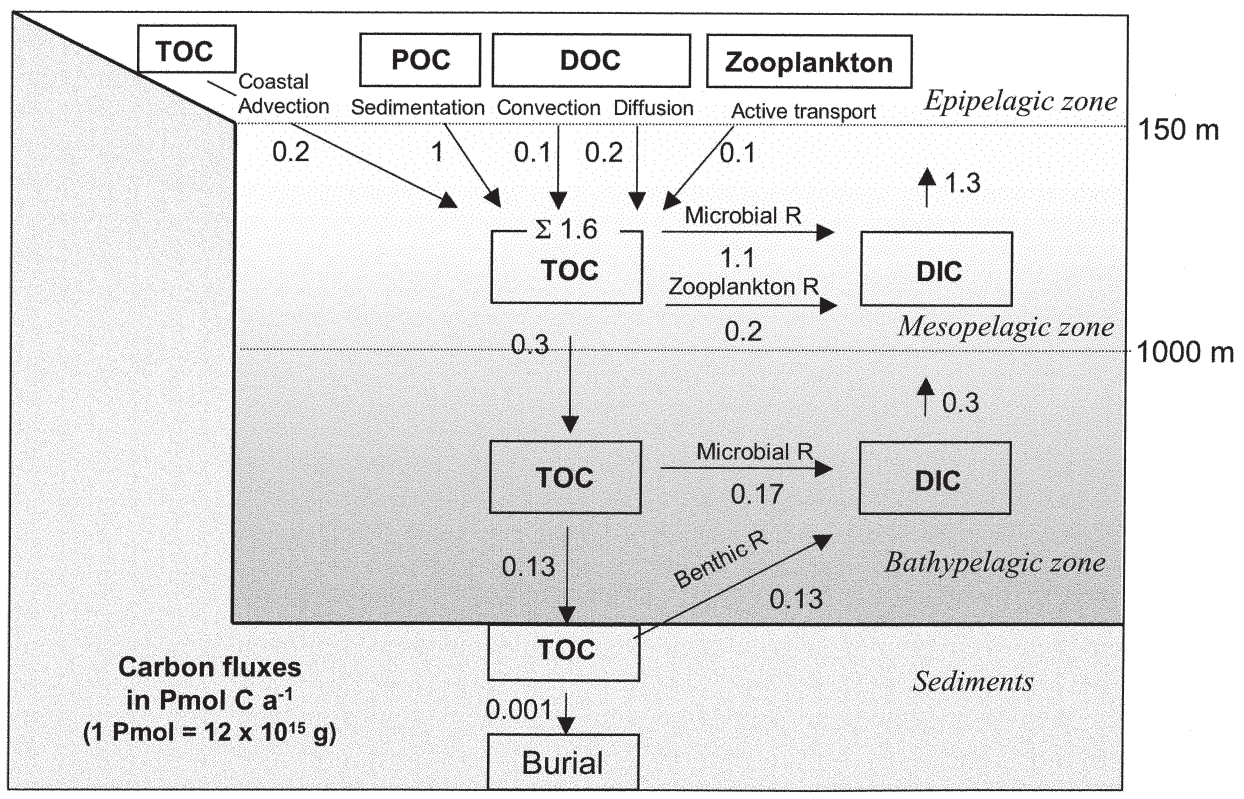

Figure 10.7 Carbon budget for the dark ocean. TOC $=$ Total Organic Carbon; POC $=$ Particulate Organic Carbon; DOC $=$ Dissolved Organic Carbon; DIC = Dissolved Inorganic Carbon; R = Respiration.

These estimates raise an interesting problem, for according to the calculations above, the ratio between exported production and primary production (assuming the presently accepted primary production of $3.3 \mathrm{PmolCa}^{-1}$ ) would be close to 0.5 . This $f$-ratio is much higher than currently accepted values, of about 0.2 , implying that either respiration is overestimated here or that primary production is severely underestimated. There is growing evidence that estimates of primary production, derived from extrapolation from ${ }^{14} \mathrm{C}$-based measurements, underestimate both gross and net primary production (e.g. del Giorgio and Duarte 2002; Marra 2002 and Chapter 14). If so, many models that use primary production as an input to estimate export production to the dark ocean or remineralization of organic carbon in the mesopelagic zone will severely underestimate the global fluxes of carbon and associated respiration rates. In addition, there are allocthonous carbon inputs to the ocean, from exchange with the continental shelves and atmospheric inputs that may further increase the organic matter available to be exported from the photic layer. Elucidation of the relative importance of these pathways remains critical to achieve a reliable understanding of the carbon cycle in the ocean.

Whereas an improved precision on the estimates of organic carbon inputs to the dark ocean is widely acknowledged (e.g. Ducklow et al. 2001), efforts to improve these calculations must continue and proceed in parallel with efforts to increase the very meager empirical base of direct estimates of respiration rate in the dark ocean. The synthesis presented here clearly identified respiration in the dark layers of the ocean to be a major, though largely neglected, component of the carbon flux, and, therefore, a major path in the global biogeochemical cycle of the elements.

\section{Acknowledgments}

This research has been supported by the Spanish Plan Nacional de I+D (Project COCA; REN-20001471), by a PIONIER grant (833.02.2002) of the Netherlands Organization of Scientific Research, 
and by the EU projects EVK2-CT-2001-00100, and EVK3-2001-00152 (OASIS). This is publication 3186 of the Netherlands Institute of Ecology. We thank Paul A. del Giorgio and Peter J. le B. Williams for their thoughtful reviews of the manuscript.

\section{References}

Alvarez-Salgado, X. A., Gago, J., Míguez, B. M., and Pérez, F. F. 2001. Net ecosystem production of dissolved organic carbon in a coastal upwelling system. The Ría de Vigo, Iberian margin of the North Atlantic. Limnol. Oceanogr., 46: 135-147.

Andersson, J. H., Wijsman, J. W. M., Herman, P. M. J., Middelburg, J. J., Soetaert, K., and Heip, C. 2004 Respiration patterns in the deep ocean. Geophys. Res. Lett., 31. doi: 10.1029/2003GL018756.

Antia, A. N., Koeve, W., Fisher, G., Blanz, T., SchulzBull, D., Scholten, J., Neuer, S., Kremling, K., Kuss, J., Peinert, R., Hebbeln, D., Bathmann, U., Conte, M., Fehner, U., and Zeitzschel, B. 2001. Basin-wide particulate carbon flux in the Atlantic Ocean: Regional export patterns and potential for atmospheric $\mathrm{CO}_{2}$ sequestration. Glob. Biogeochem. Cyc., 15: 845-862.

Antoine, D., André, J.-M., and Morel, A. 1996. Oceanic primary production. 2. Estimation at global scale from satellite (coastal zone color scanner) chlorophyll. Glob. Biogeochem. Cyc., 10: 57-69.

Archer, D., Peltzer, E., and Kirchman, D. L. 1997. A timescale of DOC production in equatorial Pacific surface waters. Glob. Biogeochem. Cyc., 11: 435-452.

Arístegui, J., Montero, M. F., Ballesteros, S., Basterretxea, G., and van Lenning, K. 1996. Planktonic primary production and microbial respiration measured by C-14 assimilation and dissolved oxygen changes in coastal waters of the Antarctic Peninsula during austral summer: implications for carbon flux studies. Mar. Ecol. Prog. Ser., 132: 191-201.

Arístegui, J., Duarte, C. M., Agustí, S., Doval, M., Alvarez-Salgado, X. A., and Hansell, D. A. 2002a. Dissolved organic carbon support of respiration in the dark ocean. Science, 298, 1967.

Arístegui, J., Denis, M., Almunia, J., and Montero, M. F. 2002b. Water-column remineralization in the Indian sector of the Southern Ocean during early spring. DeepSea Res. II, 49: 1707-1720.

Arístegui, J., Agustí, S., and Duarte, C. M. 2003. Respiration in the dark ocean. Geophys. Res. Lett., 30: 1041. doi:10. 1029/2002GLO16227.
Bacastow, R. and Mainer-Reimer, E. 1991. Dissolved organic carbon in modelling oceanic new production Glob. Biogeochem. Cyc., 5: 71-85.

Banoub, M. W. and Williams, P. J. le B. 1972. Measurement of microbial activity and organic material in the western Mediterranean Sea. Deep-Sea Res. I, 19: 433-443.

Barber, R. T. 1966. Interaction of bubbles and bacteria in the formation of organic aggregates in sea water. Nature, 211: $257-258$

Barton, E. D., Arístegui, J., Tett, P., Cantón, M., García-Braun, J., Hernández-León, S., Nykjaer, L., Almeida, C., Almunia, J., Ballesteros, S., Basterretxea, G., Escánez, J., García-Weill, L., Hernández-Guerra, A., López-Laatzen, F., Molina, R., Montrero, M. F., NavarroPérez, E., Rodríguez, J. M., van Lenning, K., Vélez, H., and Wild, K. 1998. The transition zone of the Canary Current upwelling region. Progr. Oceanogr., 41: 455-504.

Berger, W. H., Fisher, K., Lai, C., and Wu, G. 1987. Ocean carbon flux: global maps of primary production and export production. In C. Agegian (ed) Biogeochemical Cycle and Fluxes between the Deep Euphotic Zone and other Oceanic Realms, SIO, University of California, pp. 131-176.

Betzer, P. R., Showers, W. J., Laws, E. A., Winn, C. D., di Tullio, G. R., and Kroopnick, P. M. 1984. Primary production and particle fluxes on a transect of the equator at $153^{\circ} \mathrm{W}$ in the Pacific Ocean. Deep-Sea Res. I, 31: $1-11$.

Biddanda, B. and Benner, R. 1997. Major contribution from mesopelagic plankton to heterotrophic metabolism in the upper ocean. Deep Sea Res. I, 44: 2069-2085.

Broecker, W. S., and Peng, T. -H. 1982. Tracers in the Sea. Lamont-Doherty Geological Observatory, New York.

Broecker, W. S., Klas, M., Clark, E., Bonani, G., Ivy, S., and Wolffi, W. 1991. The influence of $\mathrm{CaCO}_{2}$ dissolution on core top radiocarbon ages for deep-sea sediments. Paleoceanography, 6: 593-608.

Buesseler, K. O. 1991. Do upper-ocean sediment traps provide an accurate record of particle flux? Nature, 353 : 420-423.

Buesseler, K. O., Steinberg, D. K., Michaels, A. F., Johnson, R. J., Andrews, J. E., Valdes, J. R., and Price, J. F. 2000. A comparison of the quantity and composition of material caught in a neutrally buoyant versus surfacetethered sediment trap. Deep-Sea Res. I, 47: 277-294.

Carlson, C. A., Ducklow, H. W., and Michaels, A. F. 1994. Annual flux of dissolved organic carbon from the euphotic zone of the northwestern Sargasso Sea. Nature, 371: 405-408.

Cherrier, J., Bauer, J. E., and Druffel, E. R. M. 1996. Utilization and turnover of labile dissolved organic matter by 
bacterial heterotrophs in eastern North Pacific surface waters. Mar. Ecol. Prog. Ser., 139: 267-279.

Cho, B. C. and Azam, F. 1988. Major role of bacteria in biogeochemical fluxes in the ocean's interior. Nature, 332: 441-443.

Christensen, J. P. 2000. A relationship between deep-sea benthic oxygen demand and oceanic primary production. Oceanol. Acta, 23: 65-82.

Christensen, J. P., Owens, T. G., Devol, A. H., and Packard, T. T. 1980. Respiration and physiological state in marine bacteria. Mar. Biol., 55: 267-276.

Christensen, J. P., Packard, T. T., Dortch, F. Q., Minas, H. J., Gascard, J. C., Richez, C., and Garfield, P. C. 1989. Carbon oxidation in the deep Mediterranean Sea: evidence for dissolved organic carbon source. Glob. Biogeochem. Cyc., 3: 315-335.

Christian, J. R., Lewis, M. R., and Karl, D. M. 1997. Vertical fluxes of carbon, nitrogen, and phosphorus in the North Pacific Subtropical Gyre near Hawaii. J. Geophys. Res., 102: 15667-15677.

Conover, R. J. 1978. Transformation of organic matter. In O. Kinne (ed) A Comprehensive, Integrated Treatise on Life in Oceans and Coastal Waters, Vol 4, Wiley, New York, pp. 221-499.

Copin-Montégut, G., and Avril, B. 1993. Vertical distribution and temporal variation on dissolved organic carbon in the North-Western Mediterranean Sea. Deep-Sea Res. I, 40: 1963-1972.

Dehairs, F., Shopova, D., Ober, S., Veth, C., and Goeyens, L. 1997. Particulate barium stocks and oxygen consumption in the Southern Ocean mesopelagic water column during spring and early summer: relationship with export production. Deep-Sea Res. II, 44: 497-516.

del Giorgio, P. A. and Cole, J. J. 2000. Bacterial energetics and growth efficiency. In D. L. Kirchman (ed) Microbial Ecology of the Oceans. Wiley-Liss, New York, pp. 289-326.

del Giorgio, P. A. and Duarte, C. M. 2002. Total respiration and the organic carbon balance of the open ocean. Nature, 420: 379-384.

Devol, A. H., and Hartnett, H. E. 2001. Role of the oxygendeficient zone in transfer of organic carbon to the deep ocean. Limnol. Oceanogr., 46: 1684-1690.

D'Hondt, S., Rutherford, S., and Spivack, A. J. 2002. Metabolic activity of subsurface life in deep-sea sediments. Science, 295: 2067-2070.

Doval, M. D., Pérez, F. F., and Berdalet, E. 1999. Dissolved and particulate organic carbon and nitrogen in the northwestern Mediterranean. Deep-Sea Res. I, 46: 511-527.
Druffel, E. R. M., Bauer, J. E., Williams, P. M., Griffin, S., and Wolgast, D. 1996. Seasonal variability of particulate organic radiocarbon in the northeast Pacific Ocean. J. Geophys. Res., 101: 20543-20552.

Duarte, C. M., and Cebrián, J. 1996. The fate of marine autotrophic production. Limnol. Oceanogr., 41: 1758-1766.

Duarte, C. M., Agustí, S., del Giorgio, P. A., and Cole, J. J. 1999. Regional carbon imbalances in the oceans. Science, 284: $1735 b$

Ducklow, H. W. 1993. Bacterioplankton distribution and production in the northwestern Indian Ocean and the Gulf of Oman, September 1986. Deep-Sea Res. II, 40: 753-771.

Ducklow, H. W. 1995. Ocean biogeochemical fluxes: New production and export of organic matter from the upper ocean. Rev. Geophys. Suppl., 31: (Part 2 Suppl.): 1271-1276.

Ducklow, H. W., Steinberg, D. K., and Buesseler, K. O. 2001. Upper ocean carbon export and the biological pump. Oceanography, 14: 50-58.

Emerson, S., Quay, P., Karl, D., Winn, C., Tupas, L., and Landry, M. 1997. Experimental determination of the organic carbon flux from open-ocean surface waters. Nature, 389: 951-954.

Epping, E., van der Zee, C., Soetaert, K., and Helder, W. 2002. On the oxidation and burial of organic carbon in sediments of the Iberian margin and Nazaré Canyon (N. E. Atlantic). Prog. Oceanogr., 52: 399-431.

Falkowski, P. G., Barber, R. T., and Smetacek, V. 1998. Biogeochemical controls and feedbacks on ocean primary production. Science, 281: 200-206.

Falkowski, P. G., Flagg, C. N., Rowe, G. T., Smith, S. L., Whitledge, T. E., and Wirick, C. D. 1988. The fate of a spring phytoplankton bloom-export or oxidation Cont. Shelf Res., 8: 457-484.

Feely, R. A., Wanninkhof, R., Cosca, C. E., Murphy, P. P., Lamb, M. F., and Steckley, M. D. 1995. $\mathrm{CO}_{2}$ distribution in the equatorial Pacific during the 1991-1992 ENSO event. Deep-Sea Res. II, 42: 365-386.

Fiadeiro, M. E., and Craig, H. 1978. Three-dimensional modeling of tracers in the deep Pacific Ocean: I. salinity and oxygen. J. Mar. Res., 36: 323-355.

Field, C. B., Behrenfeld, M. J., Randerson, J. T., and Falkowski, P. 1998. Primary production of the biosphere: integrating terrestrial and oceanic components. Science, 281: 237-240.

François, R., Honjo, S., Krishfield, R., and Manganini, S. 2002. Running the gauntlet in the twilight zone: the effect of midwater processes on the biological pump. U. S. JGOFS News, 11: 4-6. 
Gabric, A. J., García, L-, van Camp, L., Nykjaer, L., Eifler, W., and Schrimpf, W. 1993. Offshore export of shelf production in the Cape Blanc (Mauritania) giant filament as derived from coastal zone color scanner imagery. J. Geophys. Res., 98: 4697-4712.

Gardner, W., and Stephens, J. 1978. Stability and composition of terrestrially-derived dissolved organic nitrogen in continental shelf waters. Mar. Chem., 11: 335-342.

Gasol, J. M., Doval, M. D., Pinhassi, J., Calderón-Paz, J. I., Guixa-Boixareu, N., Vaqué, D., and Pedrós-Alió, C. 1998. Diel variations in bacterial heterotrophic activity and growth in the northwestern Mediterranean Sea. Mar Ecol. Prog. Ser., 164: 107-124.

Gattuso, J.-P., Franjignoulle, M., and Wollast, R. 1998. Carbon and carbonate metabolism in coastal aquatic ecosystems. Ann. Rev. Ecol. Syst., 29: 405-433.

Guo, L., Santschi, P. H., and Warnken, K. W. 1995. Dynamics of dissolved organic carbon (DOC) in oceanic environments. Limnol. Oceanogr., 40: 1392-1403.

Hansell, D. A. 2002. DOC in the global ocean carbon cycle. In D. A. Hansell, and C. A. Carlson (eds) Biogeochemistry of Marine Dissolved Organic Matter. Academic Press, San Diego, pp. 685-715.

Hansell, D. A. and Carlson, C. A. 2001. Marine dissolved organic matter and the carbon cycle. Oceanography, 14: 41-49.

Hansell, D. A., Williams, P. M., and Ward, B. B. 1993. Measurements of DOC and DON in the Southern California Bight using oxidation by high temperature combustion. Deep-Sea Res. I, 40: 219-234.

Hedges, J. I. and Keil, R. G. 1995. Sedimentary organic matter preservation: an assessment and speculative synthesis. Mar. Chem., 49: 81-115.

Hedges, J. I., Baldock, J. A., Gélinas, Y., Lee, C., Peterson, M. L., and Wakeham, S. G. 2002. The biochemical and elemental compositions of marine plankton: a NMR perspective. Mar. Chem., 78: 47-63.

Hernández-León, S., Gómez, M., Pagazaurtundua, M., Portillo-Hahnefeld, A., Montero, I., and Almeida, C. 2001. Vertical distribution of zooplankton in Canary Island waters: implications for export flux. Deep-Sea Res. I, 48: 1071-1092.

Holligan, P. M., Williams, P. J. le B., Purdie, D., and Harris, R. P. 1984. Photosynthesis, respiration and nitrogen supply of plankton populations in stratified, frontal and tidally mixed shelf waters. Mar. Ecol. Prog. Ser., 17: 201-213.

Holm-Hansen, O., Strickland, J. D. H., and Williams, P. M. 1966. A detailed analysis of biologically important substances in a profile off Southern California. Limnol. Oceanogr., 11: 548-561.
Hopkinson, C. S. Jr, Fry, B., and Nolin, A. L. 1997. Stoichiometry of dissolved organic matter dynamics on the continental shelf of the northeastern USA. Cont. Shelf Res., 17: 473-489.

Jackson, G. A. 2002. Collecting the garbage of the sea: the role of aggregation in ocean carbon transport. US JGOFS News, 11: 1-3.

Jackson, R. J. and Williams, P. M. 1985. Importance of dissolved organic nitrogen and phosphorus to biological nutrient cycling. Deep-Sea Res., 32: 225-235.

Jahnke, R. A. 1996. The global ocean flux of particulate organic carbon: areal distribution and magnitude. Glob. Biogeochem. Cyc., 10: 71-88.

Jannasch, H. W. and Wirsen, C. O. 1973. Deep-sea microorganisms: In situ response to nutrient enrichment. Science, 180: 641-643.

Jenkins, W. J. and Wallace, D. W. R. 1992. Tracer based inferences of new primary production in the sea. In P. G. Falkowski, and A. D. Woodhead (eds) Primary Productivity and Biogeochemical Cycles in the Sea. Plenum, pp. 299-316.

Joiris, C., Billen, G., Lancelot, C., Daro, M. H., Mommaerts, J. P., Bertels, A., Bossicart, M., Nijs, J., and Hecq, J. H. 1982. A budget of carbon cycling in the Belgian coastal zone: relative roles of zooplankton, bacterioplankton and benthos in the utilization of primary production. Neth. J. Sea Res., 16: 260-275.

Jørgensen, B. B. 1982. Mineralization of organic matter in the sea bed: role of sulphate reduction. Nature, 296 : 643-645.

Jørgensen, B. B. 1983. Processes at the sediment-water interface. In B. Bolin and R. B. Cook (eds) The Major Biogeochemical Cycles and their Interactions. John Wiley \& Sons, New York, pp. 477-509.

Kähler, P., Bjørnsen, P. K., Lochte, K., and Antia, A. 1997. Dissolved organic matter and its utilization by bacteria during spring in the Southern Ocean. Deep-Sea Res. II, 44: 341-353.

Karl, D. M., Christian, J. R., Dore, J. E., Hebel, D. V., Letelier, R. M., Tupas, L. M., and D. Winn. 1996. Seasonal and interannual variability in primary production and particle flux at Station ALOHA. Deep-Sea Res. II, 43: 539-568.

Karl, D. M., Hebel, D. V., Björkman, K., and Letelier, R. M. 1998. The role of dissolved organic matter release in the productivity of the oligotrophic North Pacific Ocean. Limnol. Oceanogr., 43: 1270-1286.

Karl, D., Michaels, A., Bergman, B., Capone, D., Carpenter, E., Letelier, R., Lipschutz, F., Paerl, H., Sigman, D., and Stal, L. 2002. Dinitrogen fixation in the world's oceans. Biogeochemistry, 57/58, 47-98. 
Keil, R. G., Montlucon, D. B., Prahl, F. G., and Hedges, J. I. 1994. Sorptive preservation of labile organic matter in marine sediments. Nature, 370: 549-552.

Kirchman, D. L., K'Nees, E., and Hodson, R. E. 1985. Leucine incorporation and its potential as a measure of protein synthesis by bacteria in natural aquatic systems. Appl. Environ. Microbiol., 49: 599-607.

La Ferla, R., and Azzaro, M. 2001. Microbial respiration in the Levantine Sea: evolution of the oxidative processes in relation to the main Mediterranean water masses. DeepSea Res. I, 48: 2147-2159.

Lefèvre, D., Denis, M., Lambert, C. E., and Miquel, J.- C. 1996. Is DOC the main source of organic matter remineralization in the ocean water column? J. Mar. Syst., 7: 281-294.

Lewis, M. R. 2002. Variability of plankton and plankton processes on the mesoscale. In P. J. le B. Williams, D. N. Thomas, and C. S. Reynolds (eds) Phytoplankton Productivity. Blackwell Science, Oxford, UK, pp. 141-155.

Libby, P. S., and Wheeler, P. A. 1997. Particulate and dissolved organic nitrogen in the central and eastern equatorial Pacific. Deep-Sea Res. II, 44: 345-361.

Libes, S. M. 1992. An Introduction to Marine Biogeochemistry. John Wiley \& Sons, New York.

Liu, K.-K., Atkinson, L., Chen, C. T. A., Gao, S., Hall, J., MacDonald, R. W., Talaue McManus, L., and Quiñones, R. 2000. Exploring continental margin carbon fluxes on a global scale. EOS, 81: 641-644.

Lohrenz, S. E., Knauer, G. A., Asper, V. L., Tuel, M., Michaels, A. F., and Knap, A. H. 1992. Seasonal variability in primary production and particle flux in the northwestern Sargasso Sea: U. S. JGOFS Bermuda Atlantic Time-series Study. Deep-Sea Res. I, 39: 1373-1391.

Longhurst, A. 1976. Vertical migration. In D. H. Cushing and J. J. Walsh (eds) The ecology of the seas, Blackwell, pp. 116-137.

Longhurst, A., Sathyendranath, S., Platt, T., and Caverhill, C. 1995. An estimate of global primary production in the ocean from satellite radiometer data. J. Plankton Res., 17: 1245-1272.

Luz, B., and Barkan, E. 2000. Assessment of oceanic productivity with the triple-isotope composition of dissolved oxygen. Science, 288: 2028-2031.

Martin, J. H., Knauer, G. A., Karl, D. M., and Broenkow, W. W. 1987. VERTEX: carbon cycling in the northeastern Pacific. Deep-Sea Res. I, 34, 267-285.

Marra, J. 2002. Approaches to the measurement of plankton production. In P. J. le B. Williams, D. N. Thomas, and C. S. Reynolds (eds) Phytoplankton Productivity. Blackwell Science, Oxford, UK, pp. 78-108.
McCarthy, M. D., Hedges, J. I., and Benner, R. 1996. Major biochemical composition of dissolved high molecular weight organic matter in seawater. Mar. Chem., 55: 281-297.

Michaels, A. F., Bates, N. R., Buesseler, K. O., Carlson, C. A., and Knap, A. 1994. Carbon-cycle imbalances in the Sargasso Sea. Nature, 372: 537-540.

Middelburg, J. J., Soetaert, K., and Herman, P. M. J. 1997. Empirical relationships for use in global diagenetic models. Deep-sea Res. I, 44: 327-344.

Munk, W. 1966. Abyssal recipes. Deep-Sea Res. I, 13: 707-730.

Nagata, T., Fukuda, H., Fukuda, R., and Koike, I. 2000 Bacterioplankton distribution and production in deep Pacific waters: large-scale geographic variations and possible coupling with sinking particle fluxes. Limnol. Oceanogr., 45: 419-425.

Najjar, R. G., and Keeling, R. F. 2000. Mean annual cycle of the air-sea oxygen flux: a global view. Glob. Biogeochem. Cyc., 14: 573-584.

Naqvi, S. W. A., Shailaja, M. S., Dileep Kumar, M., and Sen Gupta, R. 1996. Respiration rates in subsurface waters of the northern Indian Ocean: evidence for low decomposition rates of organic matter within the water column in the Bay of Bengal. Deep-Sea Res. II, 43: 73-81.

Pace, M. L., Knauer, G. A., Karl, D. M., and Martin, J. H. 1987. Primary production, new production and vertical fluxes in the eastern Pacific. Nature, 325: 803-804.

Packard, T. T. 1971. The measurement of respiratory electron transport activity in marine phytoplankton. J. Mar. Res., 29: 235-244.

Packard, T. T., Denis, M., Rodier, M., and Garfield, P. 1988 Deep-ocean metabolic $\mathrm{CO}_{2}$ production: calculations from ETS activity. Deep-Sea Res. I, 35: 371-382.

Parsons, T. R., Takahashi, M., and Hargrave, B. 1984. Biological Oceanographic Processes, 3rd edition. Pergamon Press, Oxford.

Platt, T., Jauhari, P., and Sathyendranath, S. 1992. The importance and measurement of new production. In P. G. Falkowski, and A. D. Woodhead (eds) Primary Productivity and Biogeochemical Cycles in the Sea. Plenum, New York, pp. 273-284.

Pomeroy, L. R., and Johannes, R. E. 1968. Occurrence and respiration of ultraplankton in the upper 500 meters of the ocean. Deep-Sea Res. I, 15: 381-391.

Pomeroy, L. R., Sheldon, J. E., and Sheldon, W. M. 1994. Changes in bacterial numbers and leucine assimilation during estimations of microbial respiratory rates in seawater by the precision Winkler method. Appl. Environ. Microbiol., 60: 328-332. 
Reimers, C. E., Jahnke, R. A., and Thomsen, L. 2001. In situ sampling in the benthic boundary layer. In B. P. Boudreau, and B. B. Jørgensen (eds) The Benthic Boundary Layer. Oxford University Press, Oxford, pp. 245-268.

Riley, G. A. 1951. Oxygen, phosphate and nitrate in the Atlantic Ocean. Bull. Bingham Oceanogr. Meteorol., 9: $5-22$.

Sambrotto, R. N., Savidge, G., Robinson, C., Boyd, P., Takahashi, T., Karl, D. M., Langdon, C., Chipman, D. Marra, J., and Codispoti, L. 1993. Elevated consumption of carbon relative to nitrogen in the surface ocean. Nature, 363: 248-250.

Savenkoff, C., Lefèvre, D., Denis, M., and Lambert, C. E. 1993a. How do microbial communities keep living in the Medieterranean outflow within northeast Atlantic intermediate waters? Deep-Sea Res. II, 40: 627-641.

Savenkoff, C., Prieur, L., Reys, J.-P., Lefèvre, D., Dallot, S., and Denis, M. 1993b. Deep microbial communities evidenced in the Liguro-Provençal front by their ETS activity. Deep-Sea Res. II, 40: 709-725.

Scholten, J. C., Fietzke, J., Vogler, S., Rutgers van der Loeff, M. M., Mangini, A., Koeve, W., Waniek, J., Stoffers, P., Antia, A., and Kuss, J. 2001. Trapping efficiencies of sediment traps from the deep Eastern North Atlantic: the ${ }^{230} \mathrm{Th}$ calibration. Deep Sea Res. II, 48: 2383-2408

Sherry, N. D., Boyd, P. W., Sugimoto, K., and Harrison, P. J. 1999. Seasonal and spatial patterns of heterotrophic bacterial production, respiration, and biomass in the subarctic NE Pacific. Deep-Sea Res. II, 46: 2557-2578.

Simon, M., Welschmeyer, N. A., and Kirchman, D. L. 1992. Bacterial production and the sinking flux of particulate organic matter in the subarctic Pacific. Deep-Sea Res. I 39: 1997-2008.

Smith, S. V. and Hollibaugh, J. T. 1993. Coastal metabolism and the oceanic organic carbon balance. Rev. Geophys. 31: 75-89.

Smith, K. L., Baldwin, R. J., and Williams, P. M. 1992. Reconciling particulate organic-carbon flux and sediment community oxygen-consumption in the deep north Pacific. Nature, 359: 313-316.

Soetaert, K., Herman, P. M. J., and Middelburg, J. J. 1996. A model of early diagenetic processes from the shelf to abyssal depths. Geochim. Cosmochim. Acta, 60: 1019-1040.

Sorokin, Y. I. 1978. Decomposition of organic matter and nutrient regeneration. In O. Kine (ed) Marine Ecology. John Wiley \& Sons, Chichester, pp. 501-506.

Souchou, P., Gasc. A., Cahet, G., Vaquer, A., Colos, Y., and Deslous-Paoli, J. M. 1997. Biogeochemical composition of Mediterranean waters outside the Thau Lagoon. Estuar. Coast. Shelf Sci., 44: 275-284.
Steinberg, D. K., Carlson, C. A., Bates, N. R., Johnson, R. J., Michaels, A. F., and Knap, A. F. 2001. Overview of the US JGOFS Bermuda Atlantic Time-series Study (BATS): a decade-scale look at ocean biology and biogeochemistry. Deep-Sea Res. II, 48: 1405-1447.

Suess, E. 1980. Particulate organic carbon flux in the oceanssurface productivity and oxygen utilization. Nature, 288: 260-263.

Takahashi, T., Broecker, W. S., and Langer, S. 1985. Redfield ratios based on chemical data from isopycnal surfaces. J. Geophys. Res., 90: 6907-6924.

Tengberg, A., De Bovee, F., Hall, P., Berelson, W., Chadwick, D., Ciceri, G., Crassous, P., Devol, A., Emerson, S., Gage, J., Glud, R., Graziottini, F., Gundersen, J., Hammond, D., Helder, W., Hinga, K., Holby, O., Jahnke, R., Khripounoff, A., Lieberman, S., Nuppenau, V., Pfannkuche, O., Reimers, C., Rowe, G., Sahami, A., Sayles, F., Schurter, M., Smallman, D., Wehrli, B., and Wilde, P. De. 1995. Benthic chamber and profiling landers in oceanography: a review of design, technical solutions and functioning. Prog. Oceanogr., 35: 253-294.

Turley, C. M. and Mackie, P. J. 1994. Biogeochemical significance of attached and free-living bacteria and the flux of particles in the NE Atlantic Ocean. Mar. Ecol. Prog. Ser., 115: 191-203.

Turley, C. M., and Stutt, E. D. 2000. Depth-related cellspecific bacterial leucine incorporation rates on particles and its biogeochemical significance in the northwest Mediterranean. Limnol. Oceanogr., 45: 408-418.

Vidal, M., Duarte, C. M., and Agustí, S. 1999. Dissolved organic nitrogen and phosphorus pools and fluxes in the Central Atlantic Ocean. Limnol. Oceanogr., 44: 106-115.

Vinogradov, M. E. 1970. Vertical distribution of the oceanic zooplankton. Israel program for scientific translations.

Walsh, J. J., Rowe, G. T., Iverson, R. L., and McRoy, C. P. 1981. Biological export of shelf carbon: a neglected sink of the global $\mathrm{CO}_{2}$ cycle. Nature, 291: 196-201.

Wheeler, P. A., Watkins, J. M., and Hansing, R. L. 1997. Nutrients, organic carbon and organic nitrogen in the upper water column of the Arctic Ocean: implications for the sources of dissolved organic carbon. Deep-Sea Res. II, 44: 1571-1592.

Whitman, W. B., Coleman, D. C., and Wiebe, W. J. 1998. Prokaryotes: the unseen majority. Proc. Natl. Acad. Sci. USA, 95: 6578-6583.

Wiebinga, C. J., and de Baar, H. J. W. 1998. Determination of the distribution of dissolved organic carbon in the Indian Sector of the Southern Ocean. Mar. Chem., 61: 185-201. 
Wijsman, J.W.M. 2001. Early Diagenetic Processes in Northwestern Black Sea Sediments. Ph.D Thesis, University of Groningen, ISBN 90-367-1337-4.

Williams, P. J. le B. 1981. Microbial contribution to overall marine plankton metabolism: Direct measurements of respiration. Oceanologr. Acta, 4: 359-364.

Williams, P. J. le B. 1995. Evidence for the seasonal accumulation of carbon-rich dissolved organic material, its scale in comparison with changes in particulate material and the consequential effect on net $\mathrm{C} / \mathrm{N}$ assimilation ratios. Mar. Chem., 51: 17-29.

Williams, P. J. le B. 2000. Heterotrophic bacteria and the dynamics of dissolved organic material. In D. L. Kirchman (ed) Microbial Ecology of the Oceans. Wiley-Liss, New York, pp. 153-200.

Williams, P. J. le B. and Jenkinson, N. W. 1982. A transportable microprocessor-controlled preciseWinkler titration suitable for field station and shipboard use. Limnol. Oceanogr., 27: 576-584.

Williams, P. J. le B. and Purdie, D. A. 1991. In vitro and in situ derived rates of gross production, net community production and respiration of oxygen in the oligotrophic subtropical gyre of the North Pacific Ocean. Deep-Sea Res. I, 38: 891-910.

Williams, P. M. 1986. In R. W. Eppley (ed) Plankton Dynamics of the Southern California Bight. Springer Verlag, Berlin, pp. 121-135.

Wollast, R., and Chou, L. 2001. Ocean Margin Exchange in the northern Gulf of Biscay: OMEX I. An introduction. Deep-Sea Res. II, 48: 2971-2978.

Wyrtki, K. 1962. The oxygen minima in relation to ocean circulation. Deep-Sea Res. I, 9: 11-23.

Yu, E. -F., Françoise R., Bacon, M. P.,Honjo, S., Fleer, A. P., Manganini, S. J., Rutgers van der Loeff, M. M., and Ittekot, V. 2001. Trapping efficiency of bottom-tethered sediment traps estimated from the intercepted fluxes of ${ }^{230} \mathrm{Th}$ and ${ }^{231} \mathrm{~Pa}$. Deep-Sea Res. I, 48: 865-889.

Zhang, J. and Quay, P. D. 1997. The total organic carbon export rate based on ${ }^{13} \mathrm{C}$ and ${ }^{12} \mathrm{C}$ of DIC budgets in the equatorial Pacific region. Deep-Sea Res. II, 44: 2163.

Zweifel, U. L., Norrman, B., and Hagström, Å. 1993. Consumption of dissolved organic carbon by marine bacteria and demand for inorganic nutrients. Mar. Ecol. Prog. Ser., 101: 23-32. 